\title{
Review \\ Physiology and Pathophysiology of Heparan Sulfate in Animal Models: Its Biosynthesis and Degradation
}

\author{
Ryuichi Mashima *, Torayuki Okuyama and Mari Ohira
}

check for updates

Citation: Mashima, R.; Okuyama, T.; Ohira, M. Physiology and Pathophysiology of Heparan Sulfate in Animal Models: Its Biosynthesis and Degradation. Int. J. Mol. Sci. 2022, 23, 1963. https://doi.org/ 10.3390/ijms23041963

Academic Editor: Ritva Tikkanen

Received: 13 January 2022

Accepted: 8 February 2022

Published: 10 February 2022

Publisher's Note: MDPI stays neutral with regard to jurisdictional claims in published maps and institutional affiliations.

Copyright: () 2022 by the authors. Licensee MDPI, Basel, Switzerland. This article is an open access article distributed under the terms and conditions of the Creative Commons Attribution (CC BY) license (https:// creativecommons.org/licenses/by/ $4.0 /)$.
Department of Clinical Laboratory Medicine, National Center for Child Health and Development, 2-10-1 Okura, Setagaya-ku, Tokyo 157-8535, Japan; okuyama-t@ncchd.go.jp (T.O.); ohira-m@ncchd.go.jp (M.O.)

* Correspondence: mashima-r@ncchd.go.jp; Fax: +81-3-3417-2238

\begin{abstract}
Heparan sulfate (HS) is a type of glycosaminoglycan that plays a key role in a variety of biological functions in neurology, skeletal development, immunology, and tumor metastasis. Biosynthesis of HS is initiated by a link of xylose to Ser residue of HS proteoglycans, followed by the formation of a linker tetrasaccharide. Then, an extension reaction of HS disaccharide occurs through polymerization of many repetitive units consisting of iduronic acid and $N$-acetylglucosamine. Subsequently, several modification reactions take place to complete the maturation of HS. The sulfation positions of $\mathrm{N-}, 2-\mathrm{O}-, 6-\mathrm{O}-$, and 3-O- are all mediated by specific enzymes that may have multiple isozymes. C5-epimerization is facilitated by the epimerase enzyme that converts glucuronic acid to iduronic acid. Once these enzymatic reactions have been completed, the desulfation reaction further modifies HS. Apart from HS biosynthesis, the degradation of HS is largely mediated by the lysosome, an intracellular organelle with acidic $\mathrm{pH}$. Mucopolysaccharidosis is a genetic disorder characterized by an accumulation of glycosaminoglycans in the body associated with neuronal, skeletal, and visceral disorders. Genetically modified animal models have significantly contributed to the understanding of the in vivo role of these enzymes. Their role and potential link to diseases are also discussed.
\end{abstract}

Keywords: heparan sulfate; knockout mice; biosynthesis; lysosome

\section{Introduction}

Heparan sulfate (HS) is a type of glycosaminoglycan (GAG) that contains many $\mathrm{O}-(1 \rightarrow 4)$-linked uronic acid and a glucosamine [1,2]. HS is widely found in tissues, playing an essential role in maintaining cellular function. In particular, the central nerve system (CNS), bone, immune system, and tumor metastasis have functional relevance to HS under (patho)physiological conditions. HS-proteoglycans (HSPGs) are proteins that are O-linked to HS through Ser residue in the core protein. The biochemical property of proteoglycan was extensively studied about four decades ago by Yanagishita and Hascall [3,4]. In contrast, HS-binding proteins are rather ambiguously defined. One clearly defined example includes a definition of any protein that binds to Heparan-Sepharose and dissociates from the resin by an increasing concentration of salt under neutral $\mathrm{pH}$ [2]. Thus, the biological effect of HS is exerted by modulation of the interaction between HSPG and HS-binding protein. The core protein of HSPG is biosynthesized in the ribosome followed by translocation to the endoplasmic reticulum (ER) and Golgi, where O-linked attachment of xylose followed by extension of HS takes place (Figure 1A). Following the formation of linker tetrasaccharide and an extension of glucuronic acid (GlcA) and N-acetylglucosamine (GlcNAc), the modification of HS by sulfation, epimerization, and desulfation modifies the bioactivity of HS (Figure 1B). In particular, there are specific enzymes that sulfate at $\mathrm{N}-$, 6-O, and 3-O of GlcNAc and 2-O of iduronic acid (IdoA) (Figure 1C). Apart from HS biosynthesis, it may be aberrantly accumulated under pathophysiological conditions. A well-known example includes mucopolysaccharidosis (MPSs), a group of genetic disorders 
that fail to properly degrade HS in the lysosome (Figure 2). While these disorders are rare, effective treatments have been developed. Enzyme replacement therapy infuses a therapeutic enzyme agent intravenously. A notable phenotype involves CNS involvement, visceral manifestations, and skeletal deformation. Among these three manifestations, enzyme replacement therapy effectively improves visceral manifestation, contributing to improving the quality of life of affected individuals.

A

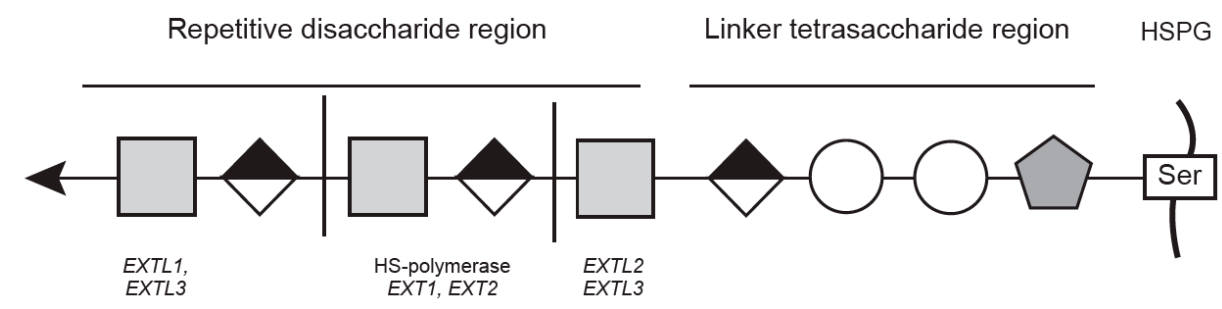

B

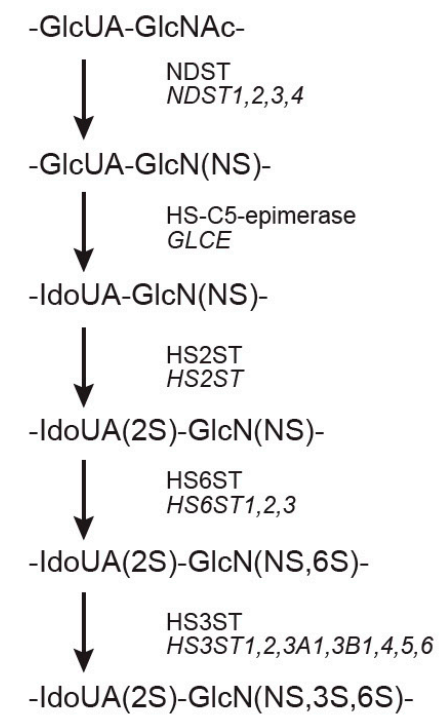

C

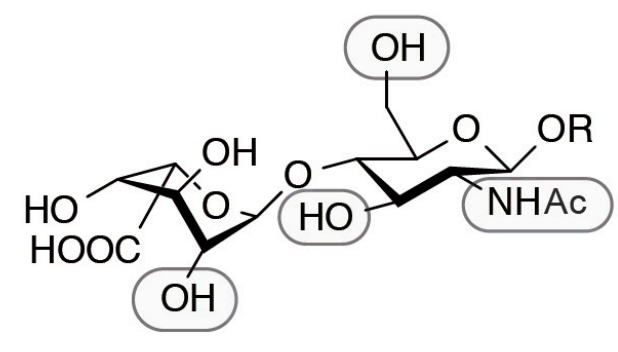

Figure 1. HS biosynthesis. (A) Extension of HS from proteoglycan. (B) Enzyme reaction of modification in HS. Note that SULF1 and SULF2 are involved in the removal of 6-O-sulfate in the last 2 steps. (C) Chemical structure of $\triangle \mathrm{UA}-\mathrm{GlcNAc}$.

From a biochemical point of view, the position and number of $N$ - and $O$-sulfate are often critical to understand biochemical property of HS. For this purpose, heparitinases with altered substrate specificity are generally used in combination. For example, heparitinase I reacts with a relatively short GAGs, whereas heparitinase III favors a larger GAG substrate. Due to the absence of distinct chromophore in HS, there are many techniques to detect HS in biological samples. Classically, fluorometric derivatization has often been used. Recently, mass spectrometric detection has become an increasingly common technique for the quantification of low molecular weight compounds. This technique also allows us to quantify HS disaccharide species in their intact or derivatized form. The intact HS disaccharides are normally chromatographed using graphite carbon-based separation [5]. In order to obtain higher sensitivity, these compounds may be derivatized using a variety of reagents, such as 3-methyl-1-phenyl-5-pyrazolone [6,7]. In this reaction, the best result is obtained under alkali conditions [8]. Alternatively, methanolysis may be used for quantification of HS disaccharide $[9,10]$. In this case, the $\mathrm{COOH}$ moiety of uronic acid and one glycosylation bond were methylated during the reaction. Such a technique has been used for the diagnosis of MPS-affected individuals. 

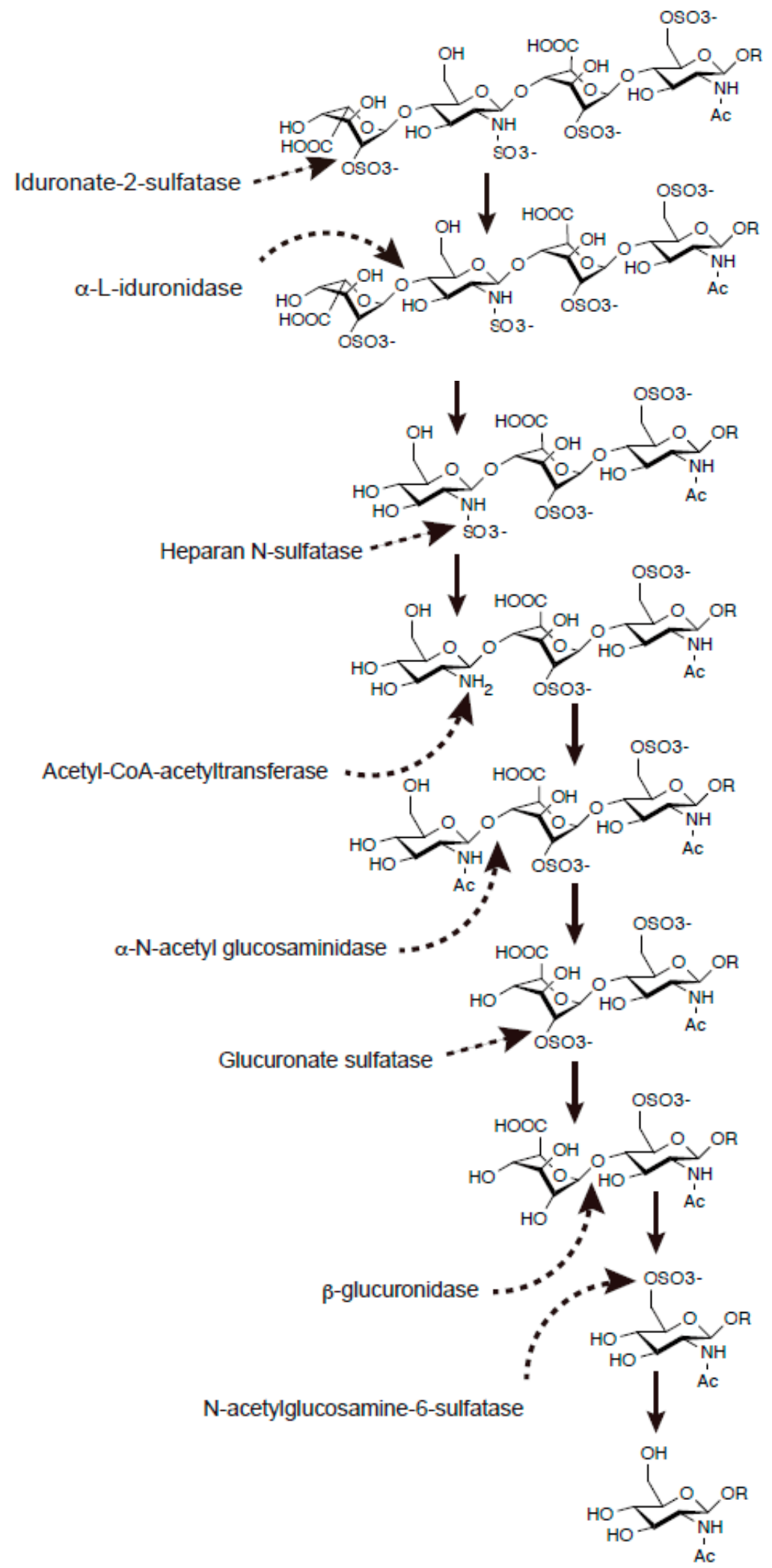

Figure 2. Degradation of HS by lysosomal enzymes involved in mucopolysaccharidosis. Enzymes involved in MPS disease subtypes are as follows: MPS I, $\alpha$-L-iduronidase; MPS II, iduronate 2-sulfatase; MPS IIIA, heparan N-sulfatase; MPS IIIB, $\alpha$-N-acetylglucosaminidase; MPS IIIC, acetyl CoA: $\alpha$-glucosaminide acetyltransferase; MPS IIID, $N$-acetylglucosamine 6-sulfatase; MPS VII, $\beta$-glucuronidase. 
Heparin is an HS-related biopolymer with different biochemical properties. First, heparin has a much smaller molecular weight (i.e., 10-15 kDa) compared with that of HS $(15-25 \mathrm{kDa})$. The average number of sulfate moiety in disaccharide in heparin is two to three compared with one to two in HS. Heparin is biosynthesized in connective tissue-typed mast cells while HS is formed in almost all cells. Heparin has a strong anticoagulant action through the activation of antithrombin. For commercial use, porcine intestine mucosa has been used as the source of heparin.

\section{Biosynthesis of HS and Phenotype of Mice Deficient in HS Biosynthesis Enzyme Genes}

HS is O-linked through Ser residue to core protein, HSPG (Figure 1). This reaction occurs in the ER and Golgi apparatus. Matured HSPG localizes either to the membrane or extracellular space. HS degradation occurs in the lysosome, a cellular compartment with an acidic environment (Figure 2). HS has many biological properties, including organ formation, the regulation of signal transduction, and the invasion and translocation of tumor. It is also known that some bacteria and viruses use HS as their receptors. For example, HS enhances corona virus infection [11]. Thus, apparently, most of the biological effects of HS may be exerted by functional modulation between HSPG and HS-binding protein. HS species with no sulfation are prominent in dried blood spots, and this is also applicable to many tissues $[12,13]$.

\subsection{Linker Tetrasaccharide Formation and Disaccharide Extension}

Heparan sulfate has a unique four oligosaccharides GlcA-Gal-Gal-Xyl, of which the reducing end $\mathrm{Xyl}$ is linked to Ser residue of proteoglycans (Figure 1A) [14]. A GlcNAc is then attached to this end for HS biosynthesis. Subsequently, the GlcA and GlcNAc are alternatively extended by GlcA transferase and GlcNAc transferase, respectively. A complex of EXT1/EXT2 enzymes catalyzes both GlcA/GlcNAc transferase reactions. EXTL2 has a GlcNAc transferase activity that terminates HS chain polymerization by the addition of GlcNAc at the linker tetrasaccharide that has been Xyl-phosphorylated by FAM20B [15]. In contrast, EXTL3 also has a GlcNAc transferase activity that similarly targets linker tetrasaccharide without Xyl phosphorylation [16]. As a result, subsequent HS polymerization by EXT1/EXT2 enzymes continues. While no study has reported the phenotype of EXTL1, B cell-specific expression of EXTL1 in mice showed a partially impaired B cell maturation [17].

A genetic defect in these genes in mice revealed that these mice are lethal [18] (Table 1). Another phenotype apparently involves abnormal chondrogenesis $[19,20]$. This was supported by a lot of evidence of a variety of conditional knockout mice. Essentially, a defect in linker tetrasaccharide formation results in osteochondroma or related chondrocyte hypertrophy. This phenotype has been extensively studied because a similar phenotype was found in humans [21]. The Ext1-dependent heparan sulfate regulates the range of IHH signaling during endochondral ossification [22]. The defect in HS formation was also affected by the BMP-mediated signaling pathway [23]. While physiological levels of HS disaccharide in chondrocytes were approximately $1 \%$ of that of CS disaccharide under normal conditions, total removal of HS through a deficiency of linker tetrasaccharide by the genetic technique caused a severe defect in chondrogenesis [24]. Other than that, abnormal neurogenesis and immune modulation have been reported. 
Table 1. Phenotype of mice that lack HS biosynthesis enzymes.

\begin{tabular}{|c|c|c|c|c|c|c|}
\hline & \multicolumn{4}{|c|}{ Mouse Phenotype } & \multirow[b]{2}{*}{ Description } & \multirow[b]{2}{*}{ Reference } \\
\hline & Lethality & $\begin{array}{l}\text { Abnormal } \\
\text { Chondrogenesis }\end{array}$ & $\begin{array}{c}\text { Neural } \\
\text { Disorders }\end{array}$ & Immunomodulation & & \\
\hline \multicolumn{7}{|c|}{ Ext1, Ext2, Ext21, Ext31 } \\
\hline$E x t 1(-/-)$ & Let & & & & Embryonic lethal & [18] \\
\hline $\operatorname{Ext1}(+/-)$ & & chondr & & & $\uparrow$ Exostosis-like phenotype & [25] \\
\hline $\operatorname{Ext1}(+/-)$ & & & & & $\begin{array}{c}\uparrow \text { Ihh signaling; } \uparrow \text { chondrocyte } \\
\text { proliferation; } \downarrow \text { hypertrophic } \\
\text { differentiation }\end{array}$ & [26] \\
\hline $\operatorname{Ext1}(+/-) ; \operatorname{Sgsh}(-/-)$ & & & & & Normal MPS IIIA pathogenesis & [27] \\
\hline$E x t 1(g t / g t)$ & Let & chondr & & & Embryonic lethal & [22] \\
\hline$E x t 1(g t / g t)$ & & & & & $\uparrow$ Chondroitin sulfate & [24] \\
\hline $\operatorname{Ext1}(g t / g t)$ & & & & & $\begin{array}{l}\uparrow \mathrm{BMP} \text { signaling in } \\
\text { engineered cartilage }\end{array}$ & [28] \\
\hline Col2-Cre;Ext1(f/f) & & chondr & & & $\begin{array}{l}\downarrow \text { Bone growth; } \downarrow \text { chondrocyte } \\
\text { hypertrophy }\end{array}$ & [29] \\
\hline Col2-Cre;Ext1(f/f) & & chondr & & & $\uparrow$ Multiple osteochondromas & [30] \\
\hline Col2-Cre;Ext1(f/+) & & chondr & & & $\uparrow$ Osteochondromas & [25] \\
\hline Col2a1-Cre;Ext1(f/f) & & chondr & & & $\begin{array}{c}\uparrow \text { Osteochondromas; } \\
\uparrow \text { phosphorylation of Smad1/5/8 }\end{array}$ & [31] \\
\hline Dermo1-Cre;Ext1(f/+) & & chondr & & & $\uparrow$ Osteochondromas & [25] \\
\hline Fsp1-Cre;Ext1(f/f) & & chondr & & & $\uparrow$ Osteochondromas & [32] \\
\hline Gdf5-Cre; Ext1(f/f) & & chondr & & & $\downarrow$ Proximal limb joints & [33] \\
\hline Prg4-Cre;Ext1(f/f) & & chondr & & & $\begin{array}{l}\uparrow \text { Hypertrophic chondrocyte; } \\
\uparrow \text { cartilage thickness }\end{array}$ & [34] \\
\hline $\begin{array}{c}\text { CaMKII- } \\
\text { Cre2834;Ext1(f/f) }\end{array}$ & & & Neural & & $\downarrow$ Excitatory synaptic transmission & [35] \\
\hline Wnt1-Cre;Ext1(f/f) & & & Neural & & $\downarrow$ Commissural axon path finding & [36] \\
\hline Lck-Cre;Ext1(f/f) & & & & Immuno & $\uparrow \mathrm{DN} 4$ cells in thymocytes & [37] \\
\hline$P d g f r \alpha-C r e ; E x t 1(f / f)$ & & & & Immuno & $\begin{array}{l}\downarrow \text { Size of fetal thymus } \\
\text { organ cultures }\end{array}$ & [38] \\
\hline Shh-Cre;Ext1(f/f) & & & & & $\begin{array}{c}\downarrow \text { Cell proliferation in stomach; } \\
\downarrow \text { FGF signaling }\end{array}$ & [39] \\
\hline Shh-Cre;Ext1(f/f) & & & & & $\begin{array}{c}\downarrow \text { Shh signaling; } \uparrow \text { branching tips; } \\
\uparrow \text { branching number }\end{array}$ & [40] \\
\hline 2.5P-Cre; Ext1(f/f) & & & & & $\begin{array}{l}\text { Abnormal podocyte morphology; } \\
\quad \rightarrow \text { albuminuria }\end{array}$ & [41] \\
\hline $\begin{array}{c}\text { Col2-rtTA- } \\
\text { Cre;Ext1(e2neofl/e2neofl) }\end{array}$ & Let & chondr & & & $\uparrow$ Multiple osteochondromas & [19] \\
\hline $\begin{array}{c}\text { Col2-rtTA- } \\
\text { Cre;Ext1(e2fl/e2fl) }\end{array}$ & & & & Immuno & $\downarrow$ Osteoarthritis & {$[42]$} \\
\hline $\begin{array}{l}\text { Tek-rtTA+;Tet- } \\
\text { Cre;Ext1(f/f) }\end{array}$ & & & & Immuno & $\begin{array}{c}\downarrow \text { Chemokine presentation in } \\
\text { epithelial cells; } \\
\downarrow \text { lymphocyte homing }\end{array}$ & {$[43]$} \\
\hline $\begin{array}{c}\text { Krt14-rtTA;Tet- } \\
\text { Cre;RosaLSL;Ext1(f/f) }\end{array}$ & & & & & $\begin{array}{l}\downarrow \text { Corneal epithelium; } \\
\downarrow \text { epithelial layers }\end{array}$ & [44] \\
\hline $\operatorname{Ext} 2(-/-)$ & & chondr & & & $\uparrow$ Exostoses & [20] \\
\hline Ext2(-/-) & & & & & $\downarrow$ FGF signaling in mutant embryo & [45] \\
\hline $\operatorname{Ext1}(+/-) ; \operatorname{Ext} 2(+/-)$ & & chondr & & & $\begin{array}{c}\uparrow \text { Exostosis-like phenotype; } \\
\downarrow \text { heparan sulfate }\end{array}$ & [25] \\
\hline $\operatorname{Ext1}(+/-) ; \operatorname{Ext} 2(+/-)$ & & & & & $\begin{array}{l}\downarrow \text { Sodium storage capacity in skin; } \\
\downarrow \text { endothelial surface layer thickness }\end{array}$ & [46] \\
\hline
\end{tabular}


Table 1. Cont.

\begin{tabular}{|c|c|c|c|c|c|c|}
\hline & \multicolumn{4}{|c|}{ Mouse Phenotype } & \multirow[b]{2}{*}{ Description } & \multirow[b]{2}{*}{ Reference } \\
\hline & Lethality & $\begin{array}{l}\text { Abnormal } \\
\text { Chondrogenesis }\end{array}$ & $\begin{array}{c}\text { Neural } \\
\text { Disorders }\end{array}$ & Immunomodulation & & \\
\hline 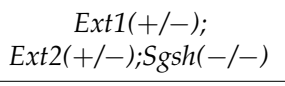 & & & Neural & & $\downarrow$ MPS IIIA pathogenesis & [27] \\
\hline Extl2(-/-) & & & Neural & & $\begin{array}{c}\uparrow \text { Chondroitin sulfate } \\
\text { proteoglycans deposition }\end{array}$ & [47] \\
\hline Extl2(-/-) & & & & Immuno & $\begin{array}{c}\uparrow \text { Incidences in non-alcoholic } \\
\text { steatohepatitis and } \\
\text { hepatocarcinoma }\end{array}$ & [48] \\
\hline Extl2(-/-) & & & & Immuno & $\begin{array}{l}\downarrow \text { Body weight; } \downarrow \text { hepatocyte in } \\
\text { CCl4-induced liver failure }\end{array}$ & [49] \\
\hline Extl2(-/-) & & & & & $\begin{array}{l}\uparrow \text { Aortic calcification in chronic } \\
\text { kidney disease }\end{array}$ & [50] \\
\hline Extl3(-/-) & Let & & & & embryonic lethality & [51] \\
\hline Nphs1-Cre;Extl3(f/f) & & & & & $\rightarrow$ Urinary albumin excretion & [52] \\
\hline \multicolumn{7}{|c|}{$N$-Deacetylase/ $N$-sulfotransferases $1-4$} \\
\hline$N d s t 1(-/-)$ & Let & & & & $\uparrow$ Respiratory distress syndrome & [53] \\
\hline$N d s t 1(-/-)$ & & chondr & & & $\downarrow$ Defective skull development & [54] \\
\hline$N d s t 1(-/-)$ & & chondr & Neural & & $\begin{array}{l}\downarrow \text { Cerebral development; } \\
\downarrow \text { craniofacial development }\end{array}$ & [55] \\
\hline$N d s t 1(-/-)$ & & & & Immuno & $\begin{array}{l}\downarrow \text { Binding affinity to vaccinia virus; } \\
\downarrow \text { binding affinity to myxoma virus. }\end{array}$ & [56] \\
\hline$N d s t 1(-/-)$ & & & & & $\begin{array}{l}\uparrow \text { Pericyte detachment; } \\
\downarrow \text { pericyte migration }\end{array}$ & [57] \\
\hline$N d s t 1(-/-)$ & & & & & $\downarrow \mathrm{Ca}^{2+}$ kinetics in myotubes & [58] \\
\hline$N d s t 1(-/-)$ & & & & & $\begin{array}{l}\downarrow \text { Differentiation of lung cells; } \\
\uparrow \text { cell proliferation. }\end{array}$ & [59] \\
\hline$N d s t 1(-/-)$ & & & & & $\begin{array}{l}\uparrow \text { Glomerular hypertrophy in the } \\
\text { kidney; } \downarrow \text { podocyte organization }\end{array}$ & [60] \\
\hline$N d s t 1(-/-)$ & & & & & $\downarrow$ Podocyte-matrix interaction & [61] \\
\hline$N d s t 1(-/-)$ & & & & & $\downarrow$ Lens development & [62] \\
\hline$N d s t 1(-/-)$ & & & & & $\downarrow$ Heart development & [63] \\
\hline$N d s t 1(-/-)$ & & & & & $\begin{array}{l}\downarrow \text { ERK signaling in lacrimal } \\
\text { gland bud }\end{array}$ & [64] \\
\hline$N d s t 1(+/-)$ & & chondr & & & $\downarrow$ Osteoarthritis & [42] \\
\hline Col2-Cre;Ndst1(f/f) & & chondr & & & $\downarrow$ Osteoarthritis & [42] \\
\hline L7-Cre;Ndst1(f/f) & & & Neural & & $\rightarrow$ Purkinje cell development & [65] \\
\hline Olig2-Cre;Ndst1(f/f) & & & Neural & & $\begin{array}{l}\uparrow \text { Lesion size; } \uparrow \text { reactivity of } \\
\text { microglia and oligodendrocyte } \\
\text { precursor cells in } \\
\text { myelin destruction }\end{array}$ & [66] \\
\hline CD11c-Cre;Ndst1(f/f) & & & & Immuno & $\begin{array}{l}\downarrow \text { Lewis lung carcinoma growth; } \\
\uparrow \text { tumor-associated CD8+ T cells }\end{array}$ & [67] \\
\hline Tek-Cre;Ndst1(f/f) & & & & Immuno & $\begin{array}{c}\downarrow \text { Leukocyte influx during } \\
\text { experimental glomerulonephritis }\end{array}$ & [68] \\
\hline Tek-Cre;Ndst1(f/f) & & & & Immuno & $\begin{array}{l}\downarrow \text { Ovalbumin-induced acute } \\
\text { airway inflammation }\end{array}$ & [69] \\
\hline Tek-Cre;Ndst1(f/f) & & & & Immuno & $\begin{array}{l}\downarrow \text { Allergen-induced airway } \\
\text { remodeling }\end{array}$ & [70] \\
\hline Tek-Cre;Ndst1(f/f) & & & & Immuno & $\downarrow$ Neutrophil trafficking & [71] \\
\hline Tek-Cre;Ndst1(f/f) & & & & Immuno & $\downarrow$ Acute renal allograft rejection & [72] \\
\hline Tie2-Cre;Ndst1(f/f) & & & & Immuno & $\rightarrow$ Neutrophil recruitment & [73] \\
\hline
\end{tabular}


Table 1. Cont.

\begin{tabular}{|c|c|c|c|c|c|c|}
\hline & \multicolumn{4}{|c|}{ Mouse Phenotype } & \multirow[b]{2}{*}{ Description } & \multirow[b]{2}{*}{ Reference } \\
\hline & Lethality & $\begin{array}{c}\text { Abnormal } \\
\text { Chondrogenesis }\end{array}$ & $\begin{array}{c}\text { Neural } \\
\text { Disorders }\end{array}$ & Immunomodulation & & \\
\hline Tie2-Cre;Ndst1(f/f) & & & & Immuno & $\begin{array}{c}\downarrow \text { Th2 cytokines; } \downarrow \text { airway } \\
\text { eosinophilia; } \downarrow \text { mucus secretion; } \\
\downarrow \text { smooth muscle mass }\end{array}$ & [74] \\
\hline Alb-Cre;Ndst1(f/f) & & & & & $\begin{array}{l}\uparrow \text { Triglyceride-rich } \\
\text { lipoprotein particles }\end{array}$ & [75] \\
\hline$A l b-C r e ; N d s t 1(f / f)$ & & & & & $\begin{array}{l}\downarrow \text { Hepatic hepcidin expression; } \\
\uparrow \text { iron accumulation in the liver } \\
\text { and serum }\end{array}$ & [76] \\
\hline Alb-Cre;Ndst1(f/f) & & & & & $\begin{array}{l}\uparrow \text { Accumulated plasma } \\
\text { triglycerides }\end{array}$ & [77] \\
\hline Le-Cre;Ndst1(f/f), & & & & & $\begin{array}{l}\downarrow \text { ERK signaling in lacrimal } \\
\text { gland bud }\end{array}$ & [64] \\
\hline MMTV-Cre;Ndst1(f/f) & & & & & $\begin{array}{l}\downarrow \text { Lobuloalveolar development in } \\
\text { mammary gland }\end{array}$ & [78] \\
\hline Tie2-Cre;Ndst1(f/f) & & & & & $\begin{array}{l}\downarrow \text { Pathogenesis of diabetic } \\
\text { nephropathy }\end{array}$ & [79] \\
\hline Tie2-Cre;Ndst1(f/f) & & & & & $\begin{array}{c}\downarrow \text { Diaphragm vascular } \\
\text { development }\end{array}$ & [80] \\
\hline Wnt-1-Cre;Ndst1(f/f), & & & & & $\begin{array}{l}\downarrow \text { ERK signaling in lacrimal } \\
\text { gland bud }\end{array}$ & [64] \\
\hline Wnt1-Cre;Ndst1(f/f) & & & & & $\downarrow$ Heart development & [63] \\
\hline Wnt1-Cre;Ndst1(f/f), & & & & & $\rightarrow$ Lacrimal gland budding & [81] \\
\hline $\begin{array}{c}\text { Alb-Cre; } N \text { dst1(f/f); } \\
\text { Apoe }(-/-)\end{array}$ & & & & & $\uparrow$ Plasma triglyceride levels & [82] \\
\hline $\begin{array}{c}\text { Krt14- } \\
\text { rtTA/TC/RosaLSL/Ndst1(f/f) }\end{array}$ & & & & & $\begin{array}{l}\downarrow \text { Corneal degeneration; } \\
\quad \downarrow \text { wound healing }\end{array}$ & [44] \\
\hline$N d s t 2(-/-)$ & & & Neural & Immuno & $\uparrow$ Neurogenic inflammation & [83] \\
\hline$N d s t 2(-/-)$ & & & & Immuno & $\begin{array}{c}\downarrow \text { Histamine release upon } \\
\text { IgE/anti-IgE challenge; } \downarrow \text { sulfated } \\
\text { heparin; } \downarrow \text { connective-tissue type } \\
\text { mast cells }\end{array}$ & [84] \\
\hline$N d s t 2(-/-)$ & & & & Immuno & $\uparrow$ Defective mast cells & [85] \\
\hline$N d s t 2(-/-)$ & & & & & $\uparrow$ Tumor growth; $\uparrow$ blood clotting & [86] \\
\hline$N d s t 2(-/-)$ & & & & & $\uparrow$ Tumor growth & [87] \\
\hline Ndst2(-/-) & & & & & $\begin{array}{l}\downarrow \text { Branching events in } \\
\text { mammary gland }\end{array}$ & [88] \\
\hline$N d s t 2(-/-)$ & & & & & $\begin{array}{l}\downarrow \text { Heparin-binding proteases; } \\
\uparrow \text { plasminogen activation }\end{array}$ & [89] \\
\hline$N d s t 2(-/-)$ & & & & & $\rightarrow$ Heart development & [63] \\
\hline$N d s t 2(-/-)$ & & & & & $\rightarrow$ Heparin sulfate composition & [58] \\
\hline$N d s t 1(-/-) ; N d s t 2(-/-)$ & & & & Immuno & $\downarrow$ Mast cell development & [85] \\
\hline Ndst1(-/-);Ndst2(-/-) & & & & & $\begin{array}{l}\downarrow \text { Induction of adipocytes and } \\
\text { neural cells; } \rightarrow \text { osteoblast }\end{array}$ & [90] \\
\hline$N d s t 1(-/-) ; N d s t 2(-/-)$ & & & & & $\downarrow$ Endothelial cell development & [91] \\
\hline$N d s t 1(-/-) ; N d s t 2(-/-)$ & & & & Immuno & $\begin{array}{l}\downarrow \text { Allergen-induced airway } \\
\text { remodeling }\end{array}$ & [70] \\
\hline$N d s t 1(-/-) ; N d s t 2(-/-)$ & & & & Immuno & $\downarrow$ Neutrophil trafficking & [71] \\
\hline $\begin{array}{c}\text { MMTV-Cre; } \\
\text { Ndst1(f/f);Ndst2(-/-), }\end{array}$ & & & & & $\begin{array}{l}\downarrow \text { Abnormal branching events in } \\
\text { mammary gland }\end{array}$ & [88] \\
\hline
\end{tabular}


Table 1. Cont.

\begin{tabular}{|c|c|c|c|c|c|c|}
\hline & \multicolumn{4}{|c|}{ Mouse Phenotype } & \multirow[b]{2}{*}{ Description } & \multirow[b]{2}{*}{ Reference } \\
\hline & Lethality & $\begin{array}{l}\text { Abnormal } \\
\text { Chondrogenesis }\end{array}$ & $\begin{array}{c}\text { Neural } \\
\text { Disorders }\end{array}$ & Immunomodulation & & \\
\hline $\begin{array}{c}\text { L7-Cre;Ndst1 } \\
(f / f) ; N d s t 2(-/-)\end{array}$ & & & Neural & & $\downarrow$ Female reproductive behavior & [65] \\
\hline $\begin{array}{l}\text { Wnt1-Cre;Ndst1(f/f); } \\
\quad \text { Ndst2(-/-) }\end{array}$ & & & & & $\downarrow$ Heart development & {$[63]$} \\
\hline $\begin{array}{l}\text { Le-Cre;Ndst1(f/f); } \\
\text { Ndst2(-/-) }\end{array}$ & & & & & $\begin{array}{l}\downarrow E R K \text { signaling in lacrimal } \\
\text { gland bud }\end{array}$ & {$[64]$} \\
\hline $\begin{array}{l}\text { Wnt1-Cre;Ndst1(f/f); } \\
\quad \text { Ndst2(-/-); }\end{array}$ & & & & & $\downarrow$ Lacrimal gland budding & {$[81]$} \\
\hline$N d s t 1(-/-) ; N d s t 3(-/-)$ & Let & & & & $\downarrow$ Embryonic development & [92] \\
\hline $\begin{array}{c}\text { Pgr-Cre;Ndst1(f/f); } \\
N d s t 2(-/-) ; N d s t 3(-/-)\end{array}$ & & & & & Infertile & [93] \\
\hline$N d s t 4(-/-)$ & & & & & $\begin{array}{l}\uparrow \text { Goblet cells; } \downarrow \text { colonocytes in the } \\
\text { proximal colon; } \uparrow \text { apoptosis in the } \\
\text { colonic epithelium }\end{array}$ & [94] \\
\hline \multicolumn{7}{|c|}{ Glucuronic acid C5-epimerase } \\
\hline Glce(-/-) & & chondr & & & $\begin{array}{c}\downarrow \text { Development of kidney; } \downarrow \text { lung } \\
\text { development; } \downarrow \text { skeletal } \\
\text { development }\end{array}$ & [95] \\
\hline Glce(-/-) & & chondr & & & $\begin{array}{l}\uparrow \text { Hedgehog signaling in } \\
\text { endochondral bones }\end{array}$ & [96] \\
\hline $\operatorname{Glce}(-/-)$ & & & & Immuno & $\downarrow$ Lymphoid organ development & [97] \\
\hline Glce(-/-) & & & & Immuno & $\begin{array}{c}\downarrow \text { B-cell maturation; } \\
\downarrow \text { APRIL-mediated survival signals }\end{array}$ & [98] \\
\hline Glce(-/-) & & & & & $\begin{array}{l}\downarrow \text { Heparin biosynthesis in } \\
\text { mast cells }\end{array}$ & [99] \\
\hline Glce (-/-) & & & & & $\downarrow$ Pericyte migration & [57] \\
\hline Glce (-/-) & & & & & $\begin{array}{l}\downarrow \text { FGF2-induced proliferation in } \\
\text { MEFs; } \downarrow \text { Erk phosphorylation }\end{array}$ & {$[100]$} \\
\hline Glce (-/-) & & & & & $\begin{array}{c}\downarrow \text { Maturation of type I alveolar } \\
\text { epithelial cells in embryonic lung; } \\
\downarrow \text { vascularization in the } \\
\text { developing lungs }\end{array}$ & [101] \\
\hline \multicolumn{7}{|c|}{ HS 2-O-sulfotransferase } \\
\hline$H s 2 s t(g t / g t)$ & Let & & & & $\begin{array}{c}\text { Neonatal lethality; } \downarrow \text { Kidney } \\
\text { development }\end{array}$ & [102] \\
\hline$H s 2 s t(g t / g t)$ & & & & & $\begin{array}{l}\downarrow \text { Development of metanephric } \\
\text { mesenchyme }\end{array}$ & [103] \\
\hline$H s 2 s t(-/-)$ & & & Neural & & $\begin{array}{c}\downarrow \text { Proper retinal ganglion } \\
\text { cell-mediated axon formation }\end{array}$ & [104] \\
\hline$H s 2 s t(-/-)$ & & & Neural & & $\downarrow$ Axon guidance & [105] \\
\hline$H s 2 s t(-/-)$ & & & Neural & & $\begin{array}{l}\downarrow \text { Cerebral cortex; } \downarrow \text { Erk } 1 / 2 \\
\text { activation at the rostral } \\
\text { telencephalic midline }\end{array}$ & [106] \\
\hline Hs2st(LacZ/LacZ) & & & Neural & & $\begin{array}{l}\downarrow \text { Migration of facial branchiomotor } \\
\text { neurons in the hindbrain. }\end{array}$ & [107] \\
\hline$A l b-C r e ; H s 2 s t(f / f)$ & & & & & $\begin{array}{c}\uparrow \text { Accumulated plasma } \\
\text { triglycerides }\end{array}$ & [77] \\
\hline Emx1-Cre;HS2st(f/f) & & & Neural & & $\begin{array}{l}\downarrow \text { Translocation signals to astroglial } \\
\text { precursors }\end{array}$ & [108] \\
\hline Zic4-Cre;HS2st(f/f) & & & Neural & & $\begin{array}{c}\downarrow \text { Translocation signals to astroglial } \\
\text { precursors }\end{array}$ & [108] \\
\hline
\end{tabular}


Table 1. Cont.

\begin{tabular}{|c|c|c|c|c|c|c|}
\hline & \multicolumn{4}{|c|}{ Mouse Phenotype } & \multirow[b]{2}{*}{ Description } & \multirow[b]{2}{*}{ Reference } \\
\hline & Lethality & $\begin{array}{c}\text { Abnormal } \\
\text { Chondrogenesis }\end{array}$ & $\begin{array}{c}\text { Neural } \\
\text { Disorders }\end{array}$ & Immunomodulation & & \\
\hline Tie2-Cre;Hs2st(f/f) & & & & Immuno & $\begin{array}{c}\uparrow \text { Binding to group B } \\
\text { Streptococcus: } \downarrow \text { formation of } \\
\text { neutrophil extracellular traps }\end{array}$ & [109] \\
\hline LysM-Cre;Hs2st(f/f) & & & & Immuno & $\rightarrow$ Neutrophil recruitment & [73] \\
\hline Tie2-Cre;Hs2st(f/f) & & & & Immuno & $\uparrow$ Th2 cytokines; $\uparrow$ eosinophils & [74] \\
\hline Tie2-Cre;Hs2st(f/f) & & & & Immuno & $\uparrow$ Neutrophil recruitment & [73] \\
\hline Tie2-Cre;Hs2st(f/f) & & & & Immuno & $\begin{array}{c}\uparrow \text { Airway eosinophilia, } \uparrow \text { mucus } \\
\text { secretion and smooth muscle mass } \\
\text { in Alternaria-challenged allergic } \\
\text { airway inflammation }\end{array}$ & [74] \\
\hline Le-Cre;Hs2st(f/f) & & & & & $\downarrow$ Lacrimal gland development & [110] \\
\hline $\begin{array}{c}\text { Le-Cre;Hs6st1(f/f); } \\
\text { Hs6st2(-/-) }\end{array}$ & & & & & $\downarrow \downarrow$ Lacrimal gland development & [110] \\
\hline $\begin{array}{c}\text { Le-Cre;Hs2st(f/f); } \\
\text { Hs6st1(f/f);Hs6st2(-/-) }\end{array}$ & & & & & $\downarrow \downarrow \downarrow$ Lacrimal gland development & [110] \\
\hline \multicolumn{7}{|c|}{ HS 6-O-sulfotransferases 1-3 } \\
\hline Hs6st1(-/-) & Let & & & & $\begin{array}{c}\downarrow \text { VEGF-A mRNA; } \downarrow \text { normal } \\
\text { placentation; } \downarrow \text { skeletal } \\
\text { development }\end{array}$ & \\
\hline Hs6st1(-/-) & & & Neural & & $\begin{array}{c}\downarrow \text { Retinal ganglion cell-mediated } \\
\text { axon formation; } \uparrow \text { prolific } \\
\text { inter-retinal innervation }\end{array}$ & [111] \\
\hline Hs6st1(-/-) & & & Neural & & $\downarrow$ Axon guidance & [105] \\
\hline Hs6st1(-/-) & & & Neural & & $\begin{array}{c}\uparrow \text { Erk activation; } \downarrow \text { corpus callosum } \\
\text { development }\end{array}$ & [112] \\
\hline Hs6st1(-/-) & & & Neural & & $\downarrow$ Cranial axon patterning & [107] \\
\hline Hs6st1(-/-) & & & & & $\downarrow$ Puberty maturation & [113] \\
\hline Alb-Cre;Hs6st1(f/f) & & & & & $\uparrow$ Plasma triglycerides & [77] \\
\hline Alb-Cre;Hs6st1(f/f) & & & & & $\begin{array}{c}\downarrow \text { Accumulated plasma } \\
\text { triglycerides }\end{array}$ & [77] \\
\hline Hs6st2(-/-) & & & & & $\begin{array}{l}\downarrow \text { Mast cell proteases in fetal } \\
\text { skin-derived mast cells }\end{array}$ & [114] \\
\hline Hs6st2(-/-) & & & Neural & & $\downarrow$ Cranial axon patterning & [107] \\
\hline Hs6st1(-/-);Hs6st2(-/-) & & & & & $\begin{array}{l}\downarrow \downarrow \text { Mast cell proteases in fetal } \\
\text { skin-derived mast cells }\end{array}$ & [114] \\
\hline $\begin{array}{l}\text { Wnt1-Cre;Hs6st1(f/f); } \\
\text { Hs6st2(-/-) }\end{array}$ & & & & & $\rightarrow$ Lacrimal gland budding & [81] \\
\hline \multicolumn{7}{|c|}{ HS 3-O-sulfotransferase 1} \\
\hline Hs3st1(-/-) & & & & Immuno & $\uparrow$ LPS-induced TNF- $\alpha$ sensitivity & [115] \\
\hline Hs3st1(-/-) on C57BL/6 & Let & & & & $\uparrow$ Lethality & [116] \\
\hline $\begin{array}{c}\text { Hs3st } 1(-/-) \text { on } \\
\text { C57BL/6/129 mix genetic } \\
\text { background }\end{array}$ & & & & & $\begin{array}{l}\downarrow \text { Anti-thrombin-binding sites in } \\
\text { carotid artery; } \rightarrow \text { tissue fibrin } \\
\text { accumulation/coagulopathy }\end{array}$ & [116] \\
\hline \multicolumn{7}{|c|}{ Sulfatase $1 / 2$} \\
\hline Sulf1(-/-) & & chondr & & & $\downarrow$ Intervertebral disc homeostasis & [117] \\
\hline Sulf1(-/-) & & & Neural & & $\begin{array}{l}\uparrow \text { Motor neuron progenitor; } \\
\downarrow \text { oligodendrocyte progenitor }\end{array}$ & [118] \\
\hline Sulf1(-/-) & & & Neural & & $\begin{array}{c}\downarrow \text { Cerebellum development; } \\
\downarrow \text { neurite outgrowth deficits } \\
\text { in neurons }\end{array}$ & [119] \\
\hline
\end{tabular}


Table 1. Cont.

\begin{tabular}{|c|c|c|c|c|c|c|}
\hline & \multicolumn{4}{|c|}{ Mouse Phenotype } & \multirow[b]{2}{*}{ Description } & \multirow[b]{2}{*}{ Reference } \\
\hline & Lethality & $\begin{array}{c}\text { Abnormal } \\
\text { Chondrogenesis }\end{array}$ & $\begin{array}{c}\text { Neural } \\
\text { Disorders }\end{array}$ & Immunomodulation & & \\
\hline Sulf1(-/-) & & & Neural & & $\begin{array}{l}\downarrow \text { Conversion of motor neurons to } \\
\text { oligodendrocyte precursor cells }\end{array}$ & [120] \\
\hline Sulf1(-/-) & & & Neural & & $\begin{array}{c}\uparrow \text { motor neuron progenitor; } \\
\downarrow \text { oligodendrocyte progenitor }\end{array}$ & [120] \\
\hline Sulf1(-/-) & & & & & $\begin{array}{l}\rightarrow \text { Kidney development; } \\
\rightarrow \text { skeletal development }\end{array}$ & [121] \\
\hline Sulf1(-/-) & & & & & $\downarrow \downarrow$ Corneal re-epithelialization & [122] \\
\hline Sulf1(-/-) & & & & & $\begin{array}{l}\downarrow \text { Angiogenesis; } \uparrow \text { HS after } \\
\text { myocardial infarction }\end{array}$ & [123] \\
\hline Sulf1 $(g t / g t)$ & & & & & $\uparrow$ Accelerated ossification & [124] \\
\hline Sulf2(-/-) & & & Neural & & $\begin{array}{l}\downarrow \text { Brain development; } \downarrow \text { neuronal } \\
\text { and behavioral plasticity }\end{array}$ & [125] \\
\hline Sulf2(-/-) & & & Neural & & $\begin{array}{l}\downarrow \text { Neurite outgrowth; } \\
\uparrow \text { hydrocephalus }\end{array}$ & [125] \\
\hline Sulf2(-/-) & & & Neural & & $\begin{array}{l}\downarrow \text { Cerebellum development; } \\
\downarrow \text { neurite outgrowth deficits } \\
\text { in neurons }\end{array}$ & [119] \\
\hline Sulf2(-/-) & & & Neural & & $\begin{array}{l}\downarrow \text { Conversion of motor neurons to } \\
\text { oligodendrocyte precursor cells }\end{array}$ & [120] \\
\hline Sulf2(-/-) & & & Neural & & $\begin{array}{l}\uparrow \text { Motor neuron progenitor; } \\
\downarrow \text { oligodendrocyte progenitor }\end{array}$ & [120] \\
\hline Sulf2(-/-) & & & Neural & & $\begin{array}{l}\downarrow \text { Novel cell population } \\
\text { (Olig2+Sox10-) }\end{array}$ & [126] \\
\hline Sulf2(-/-) & & & & & $\begin{array}{c}\downarrow \text { Kidney development; } \downarrow \text { skeletal } \\
\text { development }\end{array}$ & [121] \\
\hline Sulf2(-/-) & & & & & $\downarrow$ Corneal re-epithelialization & [122] \\
\hline Sulf2(-/-) & & & & & $\begin{array}{l}\downarrow \text { Angiogenesis; } \uparrow \text { HS after } \\
\text { myocardial infarction }\end{array}$ & [123] \\
\hline Sulf2(gt/gt) & & & & & $\uparrow$ Accelerated ossification & [124] \\
\hline Sulf2(gt/gt) & & & & & $\downarrow$ Liver regeneration & [127] \\
\hline $\begin{array}{l}\text { Olig2-Cre;sulf2(flffl); } \\
\text { R26R-tomato }\end{array}$ & & & Neural & & $\begin{array}{l}\downarrow \text { Novel cell population } \\
\text { (Olig2+Sox10-) }\end{array}$ & [126] \\
\hline Sulf1(-/-);Sulf2(-/-) & Let & & & & $\begin{array}{l}\downarrow \text { Kidney development; } \\
\downarrow \text { skeletal development }\end{array}$ & [121] \\
\hline Sulf1(-/-);Sulf2(-/-) & & chondr & & & $\uparrow$ Accelerated ossification & [124] \\
\hline Sulf1(-/-);Sulf2(-/-) & & & Neural & & $\begin{array}{l}\downarrow \text { Axon guidance in the } \\
\text { corticospinal tract. }\end{array}$ & [128] \\
\hline Sulf1(-/-);Sulf2(-/-) & & & Neural & & $\begin{array}{l}\downarrow \text { Motor function Sulf1/2 DKO } \\
\text { mice on C57BL/ } 6 \text { and CD1d } \\
\text { genetic background }\end{array}$ & [129] \\
\hline Sulf1(-/-);Sulf2(-/-) & & & & & $\begin{array}{l}\uparrow \text { Glomerular cellularity; } \\
\uparrow \text { albuminuria in } \\
\text { streptozotocin-induced } \\
\text { diabetic model }\end{array}$ & [130] \\
\hline Sulf1(-/-);Sulf2(-/-) & & & & & $\downarrow$ Esophageal contractile & [131] \\
\hline Sulf1(-/-);Sulf2(-/-) & & & & & $\downarrow$ Spermatogonial stem cells & [132] \\
\hline Sulf1(-/-);Sulf2(-/-) & & & & & $\downarrow \downarrow$ Corneal re-epithelialization & [122] \\
\hline
\end{tabular}


Table 1. Cont.

\begin{tabular}{|c|c|c|c|c|c|c|}
\hline & \multicolumn{4}{|c|}{ Mouse Phenotype } & \multirow[b]{2}{*}{ Description } & \multirow[b]{2}{*}{ Reference } \\
\hline & Lethality & $\begin{array}{c}\text { Abnormal } \\
\text { Chondrogenesis }\end{array}$ & $\begin{array}{c}\text { Neural } \\
\text { Disorders }\end{array}$ & Immunomodulation & & \\
\hline Sulf1 $(g t / g t) ; S u l f 2(g t / g t)$ & Let & chondr & & & $\begin{array}{l}\downarrow \text { Bone development; } \\
\downarrow \text { kidney development }\end{array}$ & {$[121]$} \\
\hline Sulf1 $(g t / g t) ; S u l f 2(g t / g t)$ & & chondr & & & $\begin{array}{c}\downarrow \text { Body weight; } \\
\text { 个accelerated ossification }\end{array}$ & {$[124]$} \\
\hline $\begin{array}{c}\text { Surfactant protein } \\
\text { C-rtTA;TetO- } \\
\text { Cre;Sulf1(f/f);Sulf2(f/f) }\end{array}$ & & & & Immuno & $\begin{array}{c}\uparrow \text { Neutrophil infiltration; } \\
\uparrow \text { bleomycin-induced mortality }\end{array}$ & {$[133]$} \\
\hline
\end{tabular}

$\downarrow$, Decrease; $\uparrow$, increase; $\rightarrow$, no change; + , reported; f, flox; gt, gene trap; Let, lethal; chondr, Abnormal chondrogenesis; Neural, Neural disorders; Immuno, Immunomodulation.

\subsection{Modification Reactions}

\subsection{1. $\mathrm{N}$ - and $\mathrm{O}$-sulfation}

HS is susceptible to $\mathrm{N}$ - and $\mathrm{O}$-sulfation. There are four $\mathrm{N}$-deacetylase $/ \mathrm{N}$-sulfotransferases (NDSTs), one 2-O-sulfotransfease (HS2ST), three 6-O-sulfotransferases (HS6ST), and seven 3-O-sulfotransferases (HS3ST) in humans and mice (Figure 1B). Because these enzyme reactions are not strictly sequential, there is variation of the HS disaccharide in terms of the position and degree of sulfation. NDST plays a key role in immune modulation. In contrast, both HS2ST and HS6ST affect the tubular formation of mesenchymal organs.

\section{NDST}

Similar to a mouse lacking EXT1/EXT2 enzymes, the lack of the NDST1 enzyme leads to neonatal lethality [53]. These mice also have a defect in bone and CNS development [55]. The defect in NDST enzyme leads to an increasing accumulation of heparin in mast cells, suggesting that $N$-sulfation could activate downstream sulfatases, such as HS2ST, HS6ST, and HS3ST, by an uncharacterized mechanism [134].

Apart from these globally Ndst1-deficient mice, the distinct role of NDST is best described in immune modulation. This is correlated with the expression of a chemokine receptor on endothelial cells, where its contact with leukocytes plays a key role in leukocyte migration. Notably, a recent report described that a conditional NDST1-deficient mouse exhibited impaired rejection in an acute renal allograft model [72].

\section{HS2ST}

HS2ST is a unique sulfotransferase that specifically catalyzes 2-O-sulfation in mammals (Figure 1C). In Hs2st(-/-) mice, 2-O-sulfate HS disaccharide was absent while compensatory accumulation of $\mathrm{N}$ - and 6-O-sulfate was reported [135]. These mice are embryonic lethal with renal agenesis [102]. There are several defects in CNS, such as retinal axon guidance [104], astroglial translocation [108], and facial branchiomotor neurons in the hindbrain [107]. A study using conditional knockout mice revealed that both the endothelial expression of HS2ST attenuates the rolling velocity of neutrophil and enhances IL-8- and MIP-2-induced neutrophilic infiltration [73]. Consistent with this immunomodulatory role, reduced formation of the neutrophil extracellular trap with increasing binding to group $B$ Streptococcus was reported [109]. Thus, HS2ST also plays an important role in immunity to infections. Attenuated expression of $\mathrm{Hs} 2 \mathrm{st}$ in gene trap mice was shown to impair the development of the kidney [102] and laminal grands [110]. No chondrocyte phenotype was reported in Hs2st (-/-) mice.

\section{HS6ST}

HS6ST introduces a sulfate at the 6-O position of $\mathrm{N}$-acetylgluctosamine in HS. This position has been suggested as a critical point for the interaction with FGF2 receptors that ultimately leads to activation of Erk [136]. In Hs6st1(-/-) mice, abnormal axon 
patterning in retinal ganglion cells [104], cranial axon guidance [107], and corpus callosum development [105] are the reported CNS phenotypes in murine models. Although there was no detailed study for these phenotypes, a lack of HS6ST1 enzyme might modulate the FGF2-mediated signaling pathway in neural cells, such as neuronal stem/progenitor cells. In Hs6st1(-/-);Hs6st2(-/-) double knockout mice, the percentage of 6-O-sulfation was almost completely abolished, with reduced tryptase activity in fetal skin-derived mast cells [114]. Because mast cells are heparin-producing cells [91], as described, thus attenuated production of heparin in these mice could either inhibit the gene expression or the extracellular release of trypase in this model.

\section{HS3ST}

HS3ST has been suggested to be associated with the generation of heparin because heparin is heavily sulfated compared with heparan sulfate. Specifically, the 3-O position of galactose is sulfated in heparin by enzymatic action of HS3ST. The Hs3st1(-/-) mice were established [116]. They exhibited a reduced antithrombin-binding area in the carotid artery with normal tissue fibrin accumulation. In an LPS-challenged model, an increasing sensitivity to TNF- $\alpha$ was reported, suggesting an enhanced immune reaction in these mice [115]. In Drosophila, a reduction of Hs3st-B, an ortholog of Hs3st3b1 in humans, leads to a neurogenic phenotype through Notch signaling [137]. However, a similar phenotype in humans was not reported.

\subsubsection{Glucuronic Acid C5-epimerization}

Glucuronic acid C5-epimerase (GLCE) is a unique enzyme that catalyzes the epimerization of glucuronic acid to iduronic acid [138]. This conversion occurs by catalyzing the isomerization of an equatorial $\mathrm{COOH}$ in glucuronic acid at $\mathrm{C} 5$ to an axial $\mathrm{COOH}$ in iduronic acid. The resulting sulfate group at the $\mathrm{C} 2$-position of iduronic acid prevents C5-epimerization from catalyzing reverse epimerization [139]. Apart from the biochemical reaction that occurs in animals and in vitro assays, where a relatively small quantity is sufficient, maximization of the biochemical product is an important issue from an industrial point of view. This is also applicable to the production of heparin, an anticoagulant used clinically. Apparently, a lesser content of C2-sulfate in iduronate or higher enzyme activity of GLCE yields greater heparin production on a biochemical basis.

GLCE $(-/-)$ mice are neonatally lethal due to respiratory failure [95]. In these mice, kidney formation was not observed; delayed development of the lung and bone has also been reported. Apart from these in vivo observations, a biochemical examination revealed a lack of iduronic acid in these mice. For heparin biogenesis, GLCE is unambiguously essential [99]. In the most recent study, histological analysis of the lungs in embryos revealed no difference in the morphology between wild-type and mutant animals up to E16.5 [101]. However, the distal lung of E17.5-18.5 mutants is still populated by epithelial tubules, lacking the typical saccular structural characteristic of a normal E17.5 lung. Further immunostaining revealed strong signals of surfactant protein- $\mathrm{C}$ but a weaker signal of $\mathrm{T} 1 \alpha /$ podoplanin in the mutant lungs in comparison with wild-type littermates, suggesting that the differentiation of type I alveolar epithelial cells was impaired. As a potential mechanism, it has been discussed that the reduced vascularization in the developing lungs could be associated with a failure of maturation of these cells.

\subsubsection{Sulfatase Reaction}

In humans and mice, there are two sulfatases that catalyze the sulfatase reaction at the 6-O position of GlcNAc. This reaction occurs only after sulfation reactions are complete. SULF1 and SULF2 are enzymes catalyzing the removal of 6-O sulfate of mature HS. These enzymes are located extracellularly, and their function has been postulated as being the regulators of cellular function by maintaining the appropriate amount of sulfate. These enzymes are active under neutral $\mathrm{pH}$; thus, they are distinct from lysosomal sulfatase. 
Sulf1(-/-) and Sulf2(-/-) have defects in CNS development. In Sulf1(-/-) mice, the neural progenitor cells to motor neuron progenitor are increasing while those to oligodendrocyte progenitor are decreasing [118,120]. Furthermore, there are two additional CNS phenotypes. One report describes impaired axon guidance in the corticospinal tract [128]. A more recent study demonstrated impaired motor functions in these mice [129], with Sulf1(-/-);Sulf2(-/-) double-deficient mice exhibiting the most severe phenotype involving embryonic development that is similarly found in Ext1/Ext2- and Ndst-deficient mice. Furthermore, the chondrogenic phenotype was also reported in Sulf1(-/-);Sulf2(-/-) double-deficient mice. Interestingly, in a gene trap (gt) experiment that inactivates Sulf1 and Sulf2 (i.e., Sulf1 $(g t / g t)$ and Sulf2 $(g t / g t))$, these mice were lethal with abnormal chondrocyte development, suggesting that a small residual enzyme activity of sulfatase enzyme is essential for embryonic lethality in mice [124]. Lastly, it is often observed that the phenotype of disease models may be altered depending on the genetic background. This is also the case in these sulfatases; namely, Sulf1(-/-);Sulf2(-/-) double-deficient mice on a C57BL/ 6 genetic background are lethal while those on a C57BL/ 6 and ICR mixed genetic background are not $[129,140]$.

\subsection{Diseases in Humans}

Disorders identified in the genes for HS biotransformation are rare in both HSbiosynthesis and HS degradation. Exostosis is a rare disease that is caused by dominant mutation of EXT1/EXT2 enzymes in humans [21,141]. Disorders caused by $N$ - and $\mathrm{O}$-sulfotransferases, $\mathrm{C} 5$-epimerase, and 6-O-sulfatases have not been described in humans.

\section{Lysosomal Storage Disorders (LSDs)}

A lysosome is a cellular compartment that hydrolyzes multiple biomolecules, such as oligosaccharides, lipids, glycolipids, sphingolipids, and mucopolysaccharides [142,143]. It is well known that the $\mathrm{pH}$ of a lysosome is maintained in the acid range. To achieve this, lysosomal v-ATPase is an essential molecular machinery that incorporates $\mathrm{H}^{+}$inside the lysosome at the expense of adenosine triphosphate. The failure in the proper regulation of this hydrolyzing activity leads to an accumulation of biomolecules in the lysosomal vacuoles. Lysosomal degradation is widely found in macrophages and phagocytes. For the proper lysosomal targeting of enzymes and proteins, these biomolecules are normally posttranscriptionally modified with mannose-6-phosphate. This ligand, mannose-6-phosphate, binds to a cation-independent mannose phosphate receptor that is expressed on the lysosomal membrane. Thus, once a mature LSD enzyme is endocytosed, this enzyme is selectively targeted to the lysosome. This mechanism is known as cross-correction [144]. Today, a lot of therapeutic strategies, such as hematopoietic stem cell transplantation, enzyme replacement therapy, and gene therapy, have been developed based on this mechanism.

LSDs are characterized by a deficiency of lysosomal enzymes, associated with an accumulation of sphingolipids, glycolipids, glycosaminoglycans, and other biological compounds [145]. We now know that approximately 50-60 genes are involved in this disorder [143]. The prevalence of classical LSDs is normally very rare, but it increases significantly when the population contains a high rate of late-onset disorders. LSDs exhibit a variety of manifestations involving the CNS, bone, and hepatosplenomegaly, but CNS involvement is commonly observed. Although the gene responsible for each disease has been identified, the cause of the disorder is not well understood. As a result of genetic surveys, accumulated evidence has indicated that there are many small populations that have a unique pathogenic mutation for LSDs. This is most evident in populations with high rates of consanguineous marriages. Among various mutations, missense mutation is commonly found in affected individuals, but this generally exhibits a milder phenotype. In contrast, a severe phenotype is usually associated with gross deletion, frameshift, recombination, and other mutations. Nonsense mutation usually leads to a severe phenotype, but occasionally it shows a milder phenotype. This partly occurs based on a mechanism called "read-through", where tRNA recruits an irrelevant amino acid as expected from the 
triplet codon. For example, the IDS R8X (c.22C >T) mutation is such a missense mutation where a termination codon appears immediately after the translation start site [146,147]. Some patients survived at the time of the survey without cognitive decline, a representative clinical manifestation of the mild type of MPS II [146]. The frequency of read-through is low in all missense mutations but is occasionally identified by genetic testing. The reason why this is not a general mechanism remains largely unknown. To facilitate read-through, some antibiotic agents, such as aminoglycoside, are used in vitro [148].

Mucopolysaccharidosis (MPS) is characterized an accumulation of glycosaminoglycans in the body that affects multiple organs (Figure 2). There is a distinct substrate specificity of enzymes responsible for pathogenesis. MPS I and II are caused by $\alpha$-L-iduronidase and iduronate-2-sulfatase that accumulate dermatan sulfate (DS) and HS at the same time. Four disease subtypes of MPS III, namely MPS IIIA-D, are caused by $N$-sulfoglucosamine sulfohydrolase, $\alpha-N$-acetylglucosaminidase, heparan- $\alpha$-glucosaminide $N$-acetyltransferase, and $N$-acetylglucosamine 6-sulfatase, respectively, which specifically increase HS. MPS IVA is caused by $N$-acetylgalactosamine-6-sulfatase, which increases keratan sulfate. MPS VI is caused by $N$-acetylgalactosamine 4 -sulfatase, which increases DS. MPS VII is caused by $\beta$-glucuronidase, which increases DS, HS, and hyarulonate.

A widely accepted therapy for LSDs includes enzyme replacement therapy, which infuses recombinant human LSD enzyme [143]. Its efficacy has been demonstrated in Pompe, Fabry, and Gaucher disease and MPS I, II, IVA, and VI, respectively [142]. Among various manifestations, visceral disorder, such as hepatosplenomegaly, is a good target for this therapy. Accumulating earlier studies have demonstrated a younger brother or sister exhibits better treatment results, especially when the older brother or sister has been diagnosed. Based on this evidence, it is known that the pharmacological outcome for LSDs may be maximized when the treatment begins during an asymptomatic period [149]. Consistently, newborn screening, a public health program to identify an affected newborn in the population, has been implemented in the US, Taiwan, and other countries [150-152]. This outcome of newborn screening is generally satisfactory, especially in the US, because prompt treatment becomes available. For more than a decade, an intravenously administered therapeutic enzyme has been the only bio-engineered strategy for treatment, including CNS. Based on recent studies about the receptors on pericytes, a recombinant enzyme, fused to anti-human monoclonal antibody against these endogenous receptors has been examined with satisfactory results [153].

Importantly, lysosomal biogenesis occurs before an LSD protein becomes pathogenic [154]. Transcription factor EB (TFEB), one of three similar transcription factors in humans and mice, is an essential transcription factor that is closely associated with lysosomal biogenesis. In a resting state, TFEB is serine-phosphorylated at multiple sites by mTORC1. Among them, Ser211 has been considered the key phosphorylation site that is bound to an adaptor protein 14-3-3 [155]. When TFEB is dephosphorylated by a phosphatase calcineurin, cytosolic TFEB translocates into the nucleus, followed by an initiation of gene expression involved in both lysosomal enzymes and biogenesis. For example, the expression of LAMP2, a lysosomal membrane protein often used as a biomarker, is regulated by the TFEB-induced gene expression mechanism. Similarly, $\beta$-hexosaminidase is an LSD-related gene responsible for Sandhoff disease, another well-known biomarker for LSD. In this case, the level of GM2, a ganglioside generated from hexosaminidase enzyme reaction, is elevated as well.

\section{MPS Type II}

\subsection{Pathophysiology}

MPS II (OMIM 309900) is an X-linked disorder characterized by a deficiency in enzyme activity of iduronate-2-sulfatase (IDS, EC 3.1.6.13, Figure 2) [156]. IDS catalyzes the elimination of sulfate at the 2-O position of iduronic acid from GAGs, such as dermatan sulfate and heparan sulfate. The major manifestations include hepatosplenomegaly, skeletal deformities, valvular heart disease, enlarged tongue, upper airway obstruction, and abnormal dentition. The phenotype of MPS II is linked to an accumulation of GAGs in 
tissues. Importantly, approximately $70 \%$ of individuals have CNS involvement. In the case of the IDS gene, there is a pseudogene for the IDS, termed the IDS2, which lacks enzyme activity [146]. Although many missense mutations have been identified, it has frequently been found that the IDS mutations involve recombination, a gross deletion, and a frameshift. This is well correlated with the fact that CNS involvement is the major manifestation in this disorder. The tertiary structure of the catalytic center has long been postulated based on the similarity of the amino acid sequence and a reported tertiary structure of aryl sulfatase. Recently, crystallographic data for the IDS enzyme became available [157]. Based on this result, most missense mutations have been found in the cytosolic, transmembrane, or interface regions of the IDS protein. Mammalian sulfatases, such as IDS, arylsulfatase A and B, and cholesterol sulfatase, are known to be involved in the post-transcriptional modification of cysteine residue at the catalytic center. Formyl glycine is a modified amino acid essential for the catalytic activity of sulfatases. For this reaction, sulfatase-modifying factor 1 plays a key role [158]. In fact, the loss of this enzyme's activity leads to multiple sulfatase deficiencies, another LSD. In vitro, the co-expression of sulfatase and sulfatase-modifying factor 1 enhances sulfatase activity, raising the possibility that sulfatase agents might require full enzyme activation for therapeutic application.

\subsection{Phenotype of Mouse Model}

A mouse model lacking IDS activity has been established [159]. Although several lines have been reported to date, the best studied mouse model contains an allele of which exons 4 and 5 have been replaced with a neomycin resistance gene. The major phenotype includes splenomegaly, skeletal deformities, microgliosis, astrocytosis, and abnormal CNS function. The efficacy of many therapies, such as bone marrow transplantation, enzyme replacement therapy, and gene therapy, has been tested in this model. Among these manifestations, skeletal deformity is linked to an elevation in DS [159]. In contrast, CNS involvement is linked to an elevation in HS. When the efficacy of a recombinant enzyme of IDS fused to an antibody against human transferrin receptor was tested in a murine model, a novel IDS model expressing human transferrin by a knock-in strategy was used [153].

\subsection{Treatment}

The current standard therapy for MPS II is an enzyme replacement therapy that infuses a therapeutic recombinant enzyme intravenously [160]. This treatment has had a positive therapeutic outcome in somatic, but not neurological, manifestations. The latter is due to the blood-brain barrier, which separates the blood and brain with neuronal endothelial cells. To overcome this difficulty, the possibility of intrathecal administration has been examined [161].

\subsection{Biomarker}

An accumulation of GAGs is a hallmark of MPS II and other disease subtypes of MPS ranging from MPS I to MPS VII. Historically, an elevation in the colorimetric substance in the presence of Alcian blue or Methylene blue has been used as a measure of GAG accumulation in clinical specimens. This is based on the ionic interaction between the sulfate group and positively charged nitrogen atoms in these dyes under neutral $\mathrm{pH}$. For classification, electrophoresis has been used for the separation of DS, HS, CS, and keratan sulfate. In MPS II, together with MPS I, both HS and DS are elevated under pathophysiological conditions. In contrast, HS, DS, and keratan sulfate alone are preferentially elevated in MPS III, MPS VI, and MPS IV, respectively. These biomarkers may be quantified as a disaccharide after digestion with acid or enzyme reaction. Methanolysis and other alcoholysis of GAG into disaccharides may be performed more affordably, but quantification requires controlled experimentation because formed disaccharides undergo further degradation after a prolonged reaction period [9]. Enzyme digestion of GAG occurs under much milder conditions, such as neutral $\mathrm{pH}$, but the enzymes used for this digestion have limited availability [162]. 


\section{Future Perspectives}

These animal models are anticipated to be applied for the development of novel therapeutic agents. As mentioned, enzyme replacement therapy has been developed using these mouse models. Gene therapy that delivers therapeutic genes exogenously has attracted a lot of attention in LSD and other clinical areas. Historically, the use of lentiviral vector has been studied extensively. This technique uses autologous hematopoietic stem cells for delivery; thus, affected individuals do not need to wait long to find an HLA type-matched donor and have a reduced risk for graft-versus-host disease. More recently, adeno-associated virus (AAV) has also attracted attention for gene therapy because these vectors are not incorporated into genomes, thus the descendants of affected individuals do not have a therapeutic gene [163]. Among more than 10 serotypes of AAVs, serotype 9 has often been used because its penetration of the blood-brain barrier is better than the others.

Similarly, the roles of disease modifiers will be examined in the future. Among the reported phenotypes, CNS involvement in LSDs has suggested an association with inflammation because microglial activation is commonly found in mice and humans. A recent study in macrophage biology has suggested that macrophages can be grouped into two distinct subpopulations, such as inflammatory M1 macrophages and anti-inflammatory M2 macrophages [164]. In this classification, M1 macrophages produce inflammatory cytokines, such as TNF- $\alpha$, IFN- $\gamma$, IL-6, and others, while M2 macrophages produce IL-10 and TGF- $\beta$ and express mannose receptors and scavenger receptors. Thus, a systematic study of neuroinflammation in CNS involvement in LSD is required. Apart from inflammation, $\mathrm{X}$-inactivation is involved in the disease initiation in females with X-linked disorders, such as MPS II in LSDs. In fact, such an example has been reported in humans, although the prevalence is low. For diagnosis, the severity of the manifestation in X-linked disorders in females is commonly dissociated with the changes in biomarkers, such as accumulating substances and enzyme activity. In future studies, the molecular mechanism behind female MPS II needs to be elucidated.

Author Contributions: Conceptualization, R.M., T.O. and M.O.; writing-original draft preparation, review and editing, R.M. All authors have read and agreed to the published version of the manuscript.

Funding: This work was supported by a Grant-in-Aid for Scientific Research (C) from the Ministry of Education, Culture, Sports, Science, and Technology of Japan (19K07952) to R.M. and a Grant-in-Aid from Japan Agency for Medical Research and Development (21ae0201004h0004) to T.O.

Institutional Review Board Statement: Not applicable.

Informed Consent Statement: Not applicable.

Data Availability Statement: Not applicable.

Conflicts of Interest: The authors declare no conflict of interest.

\section{References}

1. Xu, D.; Esko, J.D. Demystifying Heparan Sulfate-Protein Interactions. Annu. Rev. Biochem. 2014, 83, 129-157. [CrossRef]

2. Sarrazin, S.; Lamanna, W.C.; Esko, J.D. Heparan sulfate proteoglycans. Cold Spring Harb. Perspect. Biol. 2011, 3, 1-33. [CrossRef]

3. Isolation and Characterization of Proteoglycans from Porcine Ovarian Follicular Fluid. Available online: https://pubmed.ncbi. nlm.nih.gov/762100/ (accessed on 13 January 2022).

4. Biosynthesis of Proteoglycans by Rat Granulosa Cells Cultured in Vitro. Available online: https://pubmed.ncbi.nlm.nih.gov/50 0720/ (accessed on 13 January 2022).

5. Oguma, T.; Tomatsu, S.; Montano, A.M.; Okazaki, O. Analytical method for the determination of disaccharides derived from keratan, heparan, and dermatan sulfates in human serum and plasma by high-performance liquid chromatography/turbo ionspray ionization tandem mass spectrometry. Anal. Biochem. 2007, 368, 79-86. [CrossRef]

6. Saville, J.T.; McDermott, B.K.; Fletcher, J.M.; Fuller, M. Disease and subtype specific signatures enable precise diagnosis of the mucopolysaccharidoses. Genet. Med. 2019, 21, 753-757. [CrossRef]

7. Saville, J.T.; Derrick-Roberts, A.L.K.; McIntyre, C.; Fuller, M. Systemic scAAV9.U1a.hSGSH Delivery Corrects Brain Biochemistry in Mucopolysaccharidosis Type IIIA at Early and Later Stages of Disease. Hum. Gene Ther. 2021, 32, 420-430. [CrossRef]

8. Mashima, R.; Okuyama, T.; Ohira, M. Biomarkers for lysosomal storage disorders with an emphasis on mass spectrometry. Int. J. Mol. Sci. 2020, 21, 2704. [CrossRef] 
9. Zhang, H.; Young, S.P.; Auray-Blais, C.; Orchard, P.J.; Tolar, J.; Millington, D.S. Analysis of Glycosaminoglycans in Cerebrospinal Fluid from Patients with Mucopolysaccharidoses by Isotope-Dilution Ultra-Performance Liquid Chromatography-Tandem Mass Spectrometry. Clin. Chem. 2011, 57, 1005-1012. [CrossRef]

10. Zhang, H.; Wood, T.; Young, S.P.; Millington, D.S. A straightforward, quantitative ultra-performance liquid chromatographytandem mass spectrometric method for heparan sulfate, dermatan sulfate and chondroitin sulfate in urine: An improved clinical screening test for the mucopolysaccharidoses. Mol. Genet. Metab. 2015, 114, 123-128. [CrossRef]

11. Clausen, T.M.; Sandoval, D.R.; Spliid, C.B.; Pihl, J.; Perrett, H.R.; Painter, C.D.; Narayanan, A.; Majowicz, S.A.; Kwong, E.M.; McVicar, R.N.; et al. SARS-CoV-2 Infection Depends on Cellular Heparan Sulfate and ACE2. Cell 2020, 183, 1043-1057.e15. [CrossRef]

12. Maccari, F.; Galeotti, F.; Mantovani, V.; Zampini, L.; Padella, L.; Rigon, L.; Concolino, D.; Fiumara, A.; Pascale, E.; Pittalà, A.; et al. Composition and structure of glycosaminoglycans in DBS from 2-3-day-old newborns for the diagnosis of mucopolysaccharidosis. Anal. Biochem. 2018, 557, 34-41. [CrossRef]

13. de Ruijter, J.; de Ru, M.H.; Wagemans, T.; IJlst, L.; Lund, A.M.; Orchard, P.J.; Schaefer, G.B.; Wijburg, F.A.; van Vlies, N. Heparan sulfate and dermatan sulfate derived disaccharides are sensitive markers for newborn screening for mucopolysaccharidoses types I, II and III. Mol. Genet. Metab. 2012, 107, 705-710. [CrossRef] [PubMed]

14. Sugahara, K.; Kitagawa, H. Heparin and heparan sulfate biosynthesis. IUBMB Life 2002, 54, 163-175. [CrossRef]

15. Nadanaka, S.; Kitagawa, H. EXTL2 controls liver regeneration and aortic calcification through xylose kinase-dependent regulation of glycosaminoglycan biosynthesis. Matrix Biol. 2014, 35, 18-24. [CrossRef] [PubMed]

16. Yamada, S. Specific functions of Exostosin-like 3 (EXTL3) gene products. Cell. Mol. Biol. Lett. 2020, 25, S11658. [CrossRef] [PubMed]

17. Duchez, S.; Pascal, V.; Cogné, N.; Jayat-Vignoles, C.; Julien, R.; Cogné, M. Glycotranscriptome study reveals an enzymatic switch modulating glycosaminoglycan synthesis during B-cell development and activation. Eur. J. Immunol. 2011, 41, 3632-3644. [CrossRef] [PubMed]

18. Lin, X.; Wei, G.; Shi, Z.; Dryer, L.; Esko, J.D.; Wells, D.E.; Matzuk, M.M. Disruption of gastrulation and heparan sulfate biosynthesis in EXT1-deficient mice. Dev. Biol. 2000, 224, 299-311. [CrossRef]

19. Jones, K.B.; Piombo, V.; Searby, C.; Kurriger, G.; Yang, B.; Grabellus, F.; Roughley, P.J.; Morcuende, J.A.; Buckwalter, J.A.; Capecchi, M.R.; et al. A mouse model of osteochondromagenesis from clonal inactivation of Ext1 in chondrocytes. Proc. Natl. Acad. Sci. USA 2010, 107, 2054-2059. [CrossRef]

20. Stickens, D.; Zak, B.M.; Rougler, N.; Esko, J.D.; Werb, Z. Mice deficient in Ext2 lack heparan sulfate and develop exostoses. Development 2005, 132, 5055-5068. [CrossRef]

21. D'arienzo, A.; Andreani, L.; Sacchetti, F.; Colangeli, S.; Capanna, R. Hereditary multiple exostoses: Current insights. Orthop. Res. Rev. 2019, 11, 199-211. [CrossRef]

22. Koziel, L.; Kunath, M.; Kelly, O.G.; Vortkamp, A. Ext1-dependent heparan sulfate regulates the range of Ihh signaling during endochondral ossification. Dev. Cell 2004, 6, 801-813. [CrossRef]

23. Matsumoto, Y.; Matsumoto, K.; Irie, F.; Fukushi, J.I.; Stallcup, W.B.; Yamaguchi, Y. Conditional ablation of the heparan sulfatesynthesizing enzyme Ext1 leads to dysregulation of bone morphogenic protein signaling and severe skeletal defects. J. Biol. Chem. 2010, 285, 19227-19234. [CrossRef] [PubMed]

24. Bachvarova, V.; Dierker, T.; Esko, J.; Hoffmann, D.; Kjellen, L.; Vortkamp, A. Chondrocytes respond to an altered heparan sulfate composition with distinct changes of heparan sulfate structure and increased levels of chondroitin sulfate. Matrix Biol. 2020, 93, 43-59. [CrossRef] [PubMed]

25. Zak, B.M.; Schuksz, M.; Koyama, E.; Mundy, C.; Wells, D.E.; Yamaguchi, Y.; Pacifici, M.; Esko, J.D. Compound heterozygous loss of Ext1 and Ext2 is sufficient for formation of multiple exostoses in mouse ribs and long bones. Bone 2011, 48, 979-987. [CrossRef] [PubMed]

26. Hilton, M.J.; Gutiérrez, L.; Martinez, D.A.; Wells, D.E. EXT1 regulates chondrocyte proliferation and differentiation during endochondral bone development. Bone 2005, 36, 379-386. [CrossRef]

27. Lamanna, W.C.; Lawrence, R.; Sarrazin, S.; Lameda-Diaz, C.; Gordts, P.L.S.M.; Moremen, K.W.; Esko, J.D. A genetic model of substrate reduction therapy for mucopolysaccharidosis. J. Biol. Chem. 2012, 287, 36283-36290. [CrossRef]

28. Gerstner, M.; Severmann, A.C.; Chasan, S.; Vortkamp, A.; Richter, W. Heparan sulfate deficiency in cartilage: Enhanced bmpsensitivity, proteoglycan production and an anti-apoptotic expression signature after loading. Int. J. Mol. Sci. 2021, $22,3726$. [CrossRef]

29. Sgariglia, F.; Candela, M.E.; Huegel, J.; Jacenko, O.; Koyama, E.; Yamaguchi, Y.; Pacifici, M.; Enomoto-Iwamoto, M. Epiphyseal abnormalities, trabecular bone loss and articular chondrocyte hypertrophy develop in the long bones of postnatal Ext1-deficient mice. Bone 2013, 57, 220-231. [CrossRef]

30. Matsumoto, K.; Irie, F.; Mackem, S.; Yamaguchi, Y. A mouse model of chondrocyte-specific somatic mutation reveals a role for Ext1 loss of heterozygosity in multiple hereditary exostoses. Proc. Natl. Acad. Sci. USA 2010, 107, 10932-10937. [CrossRef]

31. Inubushi, T.; Nozawa, S.; Matsumoto, K.; Irie, F.; Yamaguchi, Y. Aberrant perichondrial BMP signaling mediates multiple osteochondromagenesis in mice. JCI Insight 2017, 2, e90049. [CrossRef]

32. Inubushi, T.; Lemire, I.; Irie, F.; Yamaguchi, Y. Palovarotene Inhibits Osteochondroma Formation in a Mouse Model of Multiple Hereditary Exostoses. J. Bone Miner. Res. 2018, 33, 658-666. [CrossRef] 
33. Mundy, C.; Yasuda, T.; Kinumatsu, T.; Yamaguchi, Y.; Iwamoto, M.; Enomoto-Iwamoto, M.; Koyama, E.; Pacifici, M. Synovial joint formation requires local Ext1 expression and heparan sulfate production in developing mouse embryo limbs and spine. Dev. Biol. 2011, 351, 70-81. [CrossRef] [PubMed]

34. Kawashima, K.; Ogawa, H.; Komura, S.; Ishihara, T.; Yamaguchi, Y.; Akiyama, H.; Matsumoto, K. Heparan sulfate deficiency leads to hypertrophic chondrocytes by increasing bone morphogenetic protein signaling. Osteoarthr. Cartil. 2020, 28, 1459-1470. [CrossRef]

35. Irie, F.; Badie-Mahdavi, H.; Yamaguchi, Y. Autism-like socio-communicative deficits and stereotypies in mice lacking heparan sulfate. Proc. Natl. Acad. Sci. USA 2012, 109, 5052-5056. [CrossRef] [PubMed]

36. Matsumoto, Y.; Irie, F.; Inatani, M.; Tessier-Lavigne, M.; Yamaguchi, Y. Netrin-1/DCC signaling in commissural axon guidance requires cell-autonomous expression of heparan sulfate. J. Neurosci. 2007, 27, 4342-4350. [CrossRef]

37. Kerselidou, D.; Dohai, B.S.; Nelson, D.R.; Daakour, S.; de Cock, N.; Oula Hassoun, Z.A.; Kim, D.K.; Olivet, J.; El Assal, D.C.; Jaiswal, A.; et al. Alternative glycosylation controls endoplasmic reticulum dynamics and tubular extension in mammalian cells. Sci. Adv. 2021, 7, eabe8349. [CrossRef]

38. Hsu, H.P.; Chen, Y.T.; Chen, Y.Y.; Lin, C.Y.; Chen, P.Y.; Liao, S.Y.; Ciara Christianne, Y.L.; Yamaguchi, Y.; Hsu, C.L.; Dzhagalov, I.L. Heparan sulfate is essential for thymus growth. J. Biol. Chem. 2021, 296, 100419. [CrossRef]

39. Huang, M.; He, H.; Belenkaya, T.; Lin, X. Multiple roles of epithelial heparan sulfate in stomach morphogenesis. J. Cell Sci. 2018, 131, jcs210781. [CrossRef] [PubMed]

40. He, H.; Huang, M.; Sun, S.; Wu, Y.; Lin, X. Epithelial heparan sulfate regulates Sonic Hedgehog signaling in lung development. PLoS Genet. 2017, 13, 6992. [CrossRef]

41. Chen, S.; Wassenhove-McCarthy, D.J.; Yamaguchi, Y.; Holzman, L.B.; Van Kuppevelt, T.H.; Jenniskens, G.J.; Wijnhoven, T.J.; Woods, A.C.; McCarthy, K.J. Loss of heparan sulfate glycosaminoglycan assembly in podocytes does not lead to proteinuria. Kidney Int. 2008, 74, 289-299. [CrossRef]

42. Severmann, A.C.; Jochmann, K.; Feller, K.; Bachvarova, V.; Piombo, V.; Stange, R.; Holzer, T.; Brachvogel, B.; Esko, J.; Pap, T.; et al. An altered heparan sulfate structure in the articular cartilage protects against osteoarthritis. Osteoarthr. Cartil. 2020, 28, 977-987. [CrossRef]

43. Bao, X.; Moseman, E.A.; Saito, H.; Petryanik, B.; Thiriot, A.; Hatakeyama, S.; Ito, Y.; Kawashima, H.; Yamaguchi, Y.; Lowe, J.B.; et al. Endothelial heparan sulfate controls chemokine presentation in recruitment of lymphocytes and dendritic cells to lymph nodes. Immunity 2010, 33, 817-829. [CrossRef]

44. Coulson-Thomas, V.J.; Chang, S.H.; Yeh, L.K.; Coulson-Thomas, Y.M.; Yamaguchi, Y.; Esko, J.; Liu, C.Y.; Kao, W. Loss of corneal epithelial heparan sulfate leads to corneal degeneration and impaired wound healing. Investig. Ophthalmol. Vis. Sci. 2015, 56, 3004-3014. [CrossRef] [PubMed]

45. Shimokawa, K.; Kimura-Yoshida, C.; Nagai, N.; Mukai, K.; Matsubara, K.; Watanabe, H.; Matsuda, Y.; Mochida, K.; Matsuo, I. Cell Surface Heparan Sulfate Chains Regulate Local Reception of FGF Signaling in the Mouse Embryo. Dev. Cell 2011, $21,257-272$. [CrossRef] [PubMed]

46. Olde Engberink, R.H.G.; de Vos, J.; van Weert, A.; Zhang, Y.; Van Vlies, N.; van den Born, B.J.H.; Titze, J.M.; van Bavel, E.; Vogt, L. Abnormal sodium and water homeostasis in mice with defective heparan sulfate polymerization. PLoS ONE 2019, 14, e0220333. [CrossRef]

47. Pu, A.; Mishra, M.K.; Dong, Y.; Ghorbanigazar, S.; Stephenson, E.L.; Rawji, K.S.; Silva, C.; Kitagawa, H.; Sawcer, S.; Yong, V.W. The glycosyltransferase EXTL2 promotes proteoglycan deposition and injurious neuroinflammation following demyelination. $J$. Neuroinflamm. 2020, 17, 220. [CrossRef]

48. Nadanaka, S.; Hashiguchi, T.; Kitagawa, H. Aberrant glycosaminoglycan biosynthesis by tumor suppressor EXTL2 deficiency promotes liver inflammation and tumorigenesis through Toll-like 4 receptor signaling. FASEB J. 2020, 34, 8385-8401. [CrossRef]

49. Nadanaka, S.; Kagiyama, S.; Kitagawa, H. Roles of EXTL2, a member of the EXT family of tumour suppressors, in liver injury and regeneration processes. Biochem. J. 2013, 454, 133-145. [CrossRef]

50. Purnomo, E.; Emoto, N.; Nugrahaningsih, D.A.A.; Nakayama, K.; Yagi, K.; Heiden, S.; Nadanaka, S.; Kitagawa, H.; Hirata, K.I. Glycosaminoglycan overproduction in the aorta increases aortic calcification in murine chronic kidney disease. J. Am. Heart Assoc. 2013, 2, 405. [CrossRef]

51. Takahashi, I.; Noguchi, N.; Nata, K.; Yamada, S.; Kaneiwa, T.; Mizumoto, S.; Ikeda, T.; Sugihara, K.; Asano, M.; Yoshikawa, T.; et al. Important role of heparan sulfate in postnatal islet growth and insulin secretion. Biochem. Biophys. Res. Commun. 2009, 383, 113-118. [CrossRef]

52. Aoki, S.; Saito-Hakoda, A.; Yoshikawa, T.; Shimizu, K.; Kisu, K.; Suzuki, S.; Takagi, K.; Mizumoto, S.; Yamada, S.; Van Kuppevelt, T.H.; et al. The reduction of heparan sulphate in the glomerular basement membrane does not augment urinary albumin excretion. Nephrol. Dial. Transplant. 2018, 33, 26-33. [CrossRef]

53. Ringvall, M.; Ledin, J.; Holmborn, K.; Van Kuppevelt, T.; Ellin, F.; Eriksson, I.; Olofsson, A.M.; Kjellén, L.; Forsberg, E. Defective heparan sulfate biosynthesis and neonatal lethality in mice lacking N-deacetylase/N-sulfotransferase-1. J. Biol. Chem. 2000, 275, 25926-25930. [CrossRef]

54. Pallerla, S.R.; Pan, Y.; Zhang, X.; Esko, J.D.; Grobe, K. Heparan sulfate Ndst1 gene function variably regulates multiple signaling pathways during mouse development. Dev. Dyn. 2007, 236, 556-563. [CrossRef] 
55. Grobe, K.; Inatani, M.; Pallerla, S.R.; Castagnola, J.; Yamaguchi, Y.; Esko, J.D. Cerebral hypoplasia and craniofacial defects in mice lacking heparan sulfate Ndst1 gene function. Development 2005, 132, 3777-3786. [CrossRef]

56. Flores, E.B.; Bartee, M.Y.; Bartee, E. Reduced cellular binding affinity has profoundly different impacts on the spread of distinct poxviruses. PLoS ONE 2020, 15, e0231977. [CrossRef]

57. Abramsson, A.; Kurup, S.; Busse, M.; Yamada, S.; Lindblom, P.; Schallmeiner, E.; Stenzel, D.; Sauvaget, D.; Ledin, J.; Ringvall, M.; et al. Defective N-sulfation of heparan sulfate proteoglycans limits PDGF-BB binding and pericyte recruitment in vascular development. Genes Dev. 2007, 21, 316-331. [CrossRef]

58. Jenniskens, G.J.; Ringvall, M.; Koopman, W.J.H.; Ledin, J.; Kjellén, L.; Willems, P.H.G.M.; Forsberg, E.; Veerkamp, J.H.; van Kuppevelt, T.H. Disturbed Ca2+ kinetics in N-deacetylase/N-sulfotransferase-1 defective myotubes. J. Cell Sci. 2003, 116, 2187-2193. [CrossRef]

59. Hu, Z.; Wang, C.; Xiao, Y.; Sheng, N.; Chen, Y.; Xu, Y.; Zhang, L.; Mo, W.; Jing, N.; Hu, G. NDST1-dependent Heparan sulfate regulates BMP signaling and internalization in lung development. J. Cell Sci. 2009, 122, 1145-1154. [CrossRef]

60. Sugar, T.; Wassenhove-Mccarthy, D.J.; Esko, J.D.; Van Kuppevelt, T.H.; Holzman, L.; Mccarthy, K.J. Podocyte-specific deletion of NDST1, a key enzyme in the sulfation of heparan sulfate glycosaminoglycans, leads to abnormalities in podocyte organization in vivo. Kidney Int. 2014, 85, 307-318. [CrossRef]

61. Sugar, T.; Wassenhove-McCarthy, D.J.; Wayne Orr, A.; Green, J.; Van Kuppevelt, T.H.; McCarthy, K.J. N-sulfation of heparan sulfate is critical for syndecan-4-mediated podocyte cell-matrix interactions. Am. J. Physiol. Ren. Physiol. 2016, 310 , F1123-F1135. [CrossRef]

62. Pan, Y.; Woodbury, A.; Esko, J.D.; Grobe, K.; Zhang, X. Heparan sulfate biosynthetic gene Ndst1 is required for FGF signaling in early lens development. Development 2006, 133, 4933-4944. [CrossRef]

63. Pan, Y.; Carbe, C.; Kupich, S.; Pickhinke, U.; Ohlig, S.; Frye, M.; Seelige, R.; Pallerla, S.R.; Moon, A.M.; Lawrence, R.; et al. Heparan sulfate expression in the neural crest is essential for mouse cardiogenesis. Matrix Biol. 2014, 35, 253-265. [CrossRef]

64. Pan, Y.; Carbe, C.; Powers, A.; Zhang, E.E.; Esko, J.D.; Grobe, K.; Feng, G.S.; Zhang, X. Bud specific N-sulfation of heparan sulfate regulates Shp2-dependent FGF signaling during lacrimal gland induction. Development 2008, 135, 301-310. [CrossRef]

65. Lewejohann, L.; Pallerla, S.R.; Schreiber, R.S.; Gerula, J.; Grobe, K. Cerebellar Morphology and Behavioral Profiles in Mice Lacking Heparan Sulfate Ndst Gene Function. J. Dev. Biol. 2020, 8, 13. [CrossRef] [PubMed]

66. Macchi, M.; Magalon, K.; Zimmer, C.; Peeva, E.; Waly, B.E.; Brousse, B.; Jaekel, S.; Grobe, K.; Kiefer, F.; Williams, A.; et al. Mature oligodendrocytes bordering lesions limit demyelination and favor myelin repair via heparan sulfate production. Elife 2020, 9, e51735. [CrossRef] [PubMed]

67. Gupta, P.; Johns, S.C.; Kim, S.Y.; El Ghazal, R.; Zuniga, E.I.; Fuster, M.M. Functional Cellular Anti-Tumor Mechanisms are Augmented by Genetic Proteoglycan Targeting. Neoplasia 2020, 22, 86-97. [CrossRef]

68. Rops, A.L.W.M.M.; Loeven, M.A.; Van Gemst, J.J.; Eversen, I.; Van Wijk, X.M.; Dijkman, H.B.; Van Kuppevelt, T.H.; Berden, J.H.M.; Rabelink, T.J.; Esko, J.D.; et al. Modulation of heparan sulfate in the glomerular endothelial glycocalyx decreases leukocyte influx during experimental glomerulonephritis. Kidney Int. 2014, 86, 932-942. [CrossRef]

69. Zuberi, R.I.; Ge, X.N.; Jiang, S.; Bahaie, N.S.; Kang, B.N.; Hosseinkhani, R.M.; Frenzel, E.M.; Fuster, M.M.; Esko, J.D.; Rao, S.P.; et al Deficiency of Endothelial Heparan Sulfates Attenuates Allergic Airway Inflammation. J. Immunol. 2009, 183, 3971-3979. [CrossRef] [PubMed]

70. Ge, X.N.; Ha, S.G.; Rao, A.; Greenberg, Y.G.; Rushdi, M.N.; Esko, J.D.; Rao, S.P.; Sriramarao, P. Endothelial and leukocyte heparan sulfates regulate the development of allergen-induced airway remodeling in a mouse model. Glycobiology 2014, 24, 715-727. [CrossRef]

71. Wang, L.; Fuster, M.; Sriramarao, P.; Esko, J.D. Endothelial heparan sulfate deficiency impairs L-selectin- and chemokine-mediated neutrophil trafficking during inflammatory responses. Nat. Immunol. 2005, 6, 902-910. [CrossRef]

72. Chen, H.; Ambadapadi, S.; Wakefield, D.; Bartee, M.; Yaron, J.R.; Zhang, L.; Archer-Hartmann, S.A.; Azadi, P.; Burgin, M.; Borges, C.; et al. Selective Deletion of Heparan Sulfotransferase Enzyme, Ndst1, in Donor Endothelial and Myeloid Precursor Cells Significantly Decreases Acute Allograft Rejection. Sci. Rep. 2018, 8, 13433. [CrossRef] [PubMed]

73. Axelsson, J.; Xu, D.; Kang, B.N.; Nussbacher, J.K.; Handel, T.M.; Ley, K.; Sriramarao, P.; Esko, J.D. Inactivation of heparan sulfate 2-O-sulfotransferase accentuates neutrophil infiltration during acute inflammation in mice. Blood 2012, 120, 1742-1751. [CrossRef] [PubMed]

74. Ge, X.N.; Bastan, I.; Ha, S.G.; Greenberg, Y.G.; Esko, J.D.; Rao, S.P.; Sriramarao, P. Regulation of eosinophil recruitment and allergic airway inflammation by heparan sulfate proteoglycan (HSPG) modifying enzymes. Exp. Lung Res. 2018, 44, 98-112. [CrossRef] [PubMed]

75. MacArthur, J.M.; Bishop, J.R.; Stanford, K.I.; Wang, L.; Bensadoun, A.; Witztum, J.L.; Esko, J.D. Liver heparan sulfate proteoglycans mediate clearance of triglyceride-rich lipoproteins independently of LDL receptor family members. J. Clin. Investig. 2007, 117, 153-164. [CrossRef]

76. Poli, M.; Anower-E-Khuda, F.; Asperti, M.; Ruzzenenti, P.; Gryzik, M.; Denardo, A.; Gordts, P.L.S.M.; Arosio, P.; Esko, J.D. Hepatic heparan sulfate is a master regulator of hepcidin expression and iron homeostasis in human hepatocytes and mice. J. Biol. Chem. 2019, 294, 13292-13303. [CrossRef] [PubMed] 
77. Stanford, K.I.; Wang, L.; Castagnola, J.; Song, D.; Bishop, J.R.; Brown, J.R.; Lawrence, R.; Bai, X.; Habuchi, H.; Tanaka, M.; et al. Heparan sulfate 2-O-sulfotransferase is required for triglyceride-rich lipoprotein clearance. J. Biol. Chem. 2010, 285, 286-294. [CrossRef]

78. Crawford, B.E.; Garner, O.B.; Bishop, J.R.; Zhang, D.Y.; Bush, K.T.; Nigam, S.K.; Esko, J.D. Loss of the heparan sulfate sulfotransferase, Ndst1, in mammary epithelial cells selectively blocks lobuloalveolar development in mice. PLoS ONE 2010, 5, e10691. [CrossRef]

79. Talsma, D.T.; Katta, K.; Ettema, M.A.B.; Kel, B.; Kusche-Gullberg, M.; Daha, M.R.; Stegeman, C.A.; Van Den Born, J.; Wang, L. Endothelial heparan sulfate deficiency reduces inflammation and fibrosis in murine diabetic nephropathy. Lab. Investig. 2018, 98, 427-438. [CrossRef]

80. Zhang, B.; Xiao, W.; Qiu, H.; Zhang, F.; Moniz, H.A.; Jaworski, A.; Condac, E.; Gutierrez-Sanchez, G.; Heiss, C.; Clugston, R.D.; et al Heparan sulfate deficiency disrupts developmental angiogenesis and causes congenital diaphragmatic hernia. J. Clin. Investig. 2014, 124, 209-221. [CrossRef]

81. Qu, X.; Pan, Y.; Carbe, C.; Powers, A.; Grobe, K.; Zhang, X. Glycosaminoglycan-dependent restriction of FGF diffusion is necessary for lacrimal gland development. Development 2012, 139, 2730-2739. [CrossRef]

82. Ramms, B.; Patel, S.; Nora, C.; Pessentheiner, A.R.; Chang, M.W.; Green, C.R.; Golden, G.J.; Secrest, P.; Krauss, R.M.; Metallo, C.M.; et al. ApoC-III ASO promotes tissue LPL activity in the absence of apoE-mediated TRL clearance. J. Lipid Res. 2019, 60, 1379-1395. [CrossRef]

83. Karlsen, T.V.; Iversen, V.V.; Forsberg, E.; Kjellén, L.; Reed, R.K.; Gjerde, E.A.B. Neurogenic inflammation in mice deficient in heparin-synthesizing enzyme. Am. J. Physiol. Heart Circ. Physiol. 2004, 286, H884-H888. [CrossRef]

84. Forsberg, E.; Pejler, G.; Ringvall, M.; Lunderius, C.; Tomasini-Johansson, B.; Kusche-Gullberg, M.; Eriksson, I.; Ledin, J.; Hellman, L.; Kjellén, L. Abnormal mast cells in mice deficient in a heparin-synthesizing enzyme. Nature 1999, 400, 773-776. [CrossRef] [PubMed]

85. Dagälv, A.; Holmborn, K.; Kjellén, L.; Åbrink, M. Lowered expression of heparan sulfate/heparin biosynthesis enzyme Ndeacetylase/N-sulfotransferase 1 results in increased sulfation of mast cell heparin. J. Biol. Chem. 2011, 286, 44433-44440. [CrossRef] [PubMed]

86. Samoszuk, M.; Corwin, M.A. Acceleration of tumor growth and peri-tumoral blood clotting by imatinib mesylate (Gleevec $\left.{ }^{\mathrm{TM}}\right)$. Int. J. Cancer 2003, 106, 647-652. [CrossRef] [PubMed]

87. Samoszuk, M.; Corwin, M.; Yu, H.; Wang, J.; Nalcioglu, O.; Su, M.Y. Inhibition of thrombosis in melanoma allografts in mice by endogenous mast cell heparin. Thromb. Haemost. 2003, 90, 351-360. [CrossRef] [PubMed]

88. Bush, K.T.; Crawford, B.E.; Garner, O.B.; Nigam, K.B.; Esko, J.D.; Nigam, S.K. N-sulfation of heparan sulfate regulates early branching events in the developing mammary gland. J. Biol. Chem. 2012, 287, 42064-42070. [CrossRef]

89. Tchougounova, E.; Pejler, G. Regulation of extravascular coagulation and fibrinolysis by heparin-dependent mast cell chymase FASEB J. 2001, 15, 2763-2765. [CrossRef]

90. Forsberg, M.; Holmborn, K.; Kundu, S.; Dagälv, A.; Kjellén, L.; Forsberg-Nilsson, K. Undersulfation of heparan sulfate restricts differentiation potential of mouse embryonic stem cells. J. Biol. Chem. 2012, 287, 10853-10862. [CrossRef]

91. Jakobsson, L.; Kreuger, J.; Holmborn, K.; Lundin, L.; Eriksson, I.; Kjellén, L.; Claesson-Welsh, L. Heparan Sulfate in trans Potentiates VEGFR-Mediated Angiogenesis. Dev. Cell 2006, 10, 625-634. [CrossRef]

92. Pallerla, S.R.; Lawrence, R.; Lewejohann, L.; Pan, Y.; Fischer, T.; Schlomann, U.; Zhang, X.; Esko, J.D.; Grobe, K. Altered heparan sulfate structure in mice with deleted NDST3 gene function. J. Biol. Chem. 2008, 283, 16885-16894. [CrossRef]

93. Yin, Y.; Wang, A.; Feng, L.; Wang, Y.; Zhang, H.; Zhang, I.; Bany, B.M.; Ma, L. Heparan sulfate proteoglycan sulfation regulates uterine differentiation and signaling during embryo implantation. Endocrinology 2018, 159, 2459-2472. [CrossRef] [PubMed]

94. Jao, T.M.; Li, Y.L.; Lin, S.W.; Tzeng, S.T.; Yu, I.S.; Yen, S.J.; Tsai, M.H.; Yang, Y.C. Alteration of colonic epithelial cell differentiation in mice deficient for glucosaminyl N-deacetylase/N-sulfotransferase 4. Oncotarget 2016, 7, 84938-84950. [CrossRef] [PubMed]

95. Li, J.P.; Gong, F.; Hagner-McWhirter, Å.; Forsberg, E.; Åbrink, M.; Kisilevsky, R.; Zhang, X.; Lindahl, U. Targeted disruption of a murine glucuronyl C5-epimerase gene results in heparan sulfate lacking L-iduronic acid and in neonatal lethality. J. Biol. Chem. 2003, 278, 28363-28366. [CrossRef] [PubMed]

96. Dierker, T.; Bachvarova, V.; Krause, Y.; Li, J.P.; Kjellén, L.; Seidler, D.G.; Vortkamp, A. Altered heparan sulfate structure in Glce-/ - mice leads to increased Hedgehog signaling in endochondral bones. Matrix Biol. 2016, 49, 82-92. [CrossRef]

97. Reijmers, R.M.; Vondenhoff, M.F.R.; Roozendaal, R.; Kuil, A.; Li, J.-P.; Spaargaren, M.; Pals, S.T.; Mebius, R.E. Impaired Lymphoid Organ Development in Mice Lacking the Heparan Sulfate Modifying Enzyme Glucuronyl C5-Epimerase. J. Immunol. 2010, 184, 3656-3664. [CrossRef]

98. Reijmers, R.M.; Groen, R.W.J.; Kuil, A.; Weijer, K.; Kimberley, F.C.; Medema, J.P.; Van Kuppevelt, T.H.; Li, J.P.; Spaargaren, M.; Pals, S.T. Disruption of heparan sulfate proteoglycan conformation perturbs B-cell maturation and APRIL-mediated plasma cell survival. Blood 2011, 117, 6162-6171. [CrossRef]

99. Feyerabend, T.B.; Li, J.P.; Lindahl, U.; Rodewald, H.R. Heparan sulfate C5-epimerase is essential for heparin biosynthesis in mast cells. Nat. Chem. Biol. 2006, 2, 195-196. [CrossRef]

100. Jia, J.; Maccarana, M.; Zhang, X.; Bespalov, M.; Lindahl, U.; Li, J.P. Lack of L-iduronic acid in heparan sulfate affects interaction with growth factors and cell signaling. J. Biol. Chem. 2009, 284, 15942-15950. [CrossRef] 
101. Cui, H.; Cheng, X.; Batool, T.; Zhang, X.; Li, J.P. Glucuronyl C5-epimerase is crucial for epithelial cell maturation during embryonic lung development. Glycobiology 2021, 31, 223-230. [CrossRef]

102. Bullock, S.L.; Fletcher, J.M.; Beddington, R.S.P.; Wilson, V.A. Renal agenesis in mice homozygous for a gene trap mutation in the gene encoding heparan sulfate 2-sulfotransferase. Genes Dev. 1998, 12, 1894-1906. [CrossRef]

103. Shah, M.M.; Sakurai, H.; Sweeney, D.E.; Gallegos, T.F.; Bush, K.T.; Esko, J.D.; Nigam, S.K. Hs2st mediated kidney mesenchyme induction regulates early ureteric bud branching. Dev. Biol. 2010, 339, 354-365. [CrossRef]

104. Pratt, T.; Conway, C.D.; Tian, N.M.M.L.; Price, D.J.; Mason, J.O. Heparan sulphation patterns generated by specific heparan sulfotransferase enzymes direct distinct aspects of retinal axon guidance at the optic chiasm. J. Neurosci. 2006, 26, 6911-6923. [CrossRef]

105. Conway, C.D.; Howe, K.M.; Nettleton, N.K.; Price, D.J.; Mason, J.O.; Pratt, T. Heparan sulfate sugar modifications mediate the functions of Slits and other factors needed for mouse forebrain commissure development. J. Neurosci. 2011, 31, 1955-1970. [CrossRef] [PubMed]

106. Chan, W.K.; Howe, K.; Clegg, J.M.; Guimond, S.E.; Price, D.J.; Turnbull, J.E.; Pratt, T. 2-O heparan sulfate sulfation by Hs2st is required for Erk/Mapk signalling activation at the mid-gestational mouse telencephalic midline. PLoS ONE 2015, 10, e130147. [CrossRef] [PubMed]

107. Tillo, M.; Charoy, C.; Schwarz, Q.; Maden, C.H.; Davidson, K.; Fantin, A.; Ruhrberg, C. 2- and 6-O-sulfated proteoglycans have distinct and complementary roles in cranial axon guidance and motor neuron migration. Development 2016, 143, 1907-1913. [CrossRef] [PubMed]

108. Clegg, J.M.; Parkin, H.M.; Mason, J.O.; Pratt, T. Heparan sulfate sulfation by Hs2st restricts astroglial precursor somal translocation in developing mouse forebrain by a non-cell-autonomous mechanism. J. Neurosci. 2019, 39, 1386-1404. [CrossRef] [PubMed]

109. Xu, D.; Olson, J.; Cole, J.N.; van Wijk, X.M.; Brinkmann, V.; Zychlinsky, A.; Nizet, V.; Esko, J.D.; Chang, Y.C. Heparan sulfate modulates neutrophil and endothelial function in antibacterial innate immunity. Infect. Immun. 2015, 83, 3648-3656. [CrossRef]

110. Qu, X.; Carbe, C.; Tao, C.; Powers, A.; Lawrence, R.; Van Kuppevelt, T.H.; Cardoso, W.V.; Grobe, K.; Esko, J.D.; Zhang, X. Lacrimal gland development and Fgf10-Fgfr2b signaling are controlled by 2-O-and 6-O-sulfated heparan sulfate. J. Biol. Chem. 2011, 286, 14435-14444. [CrossRef]

111. Habuchi, H.; Nagai, N.; Sugaya, N.; Atsumi, F.; Stevens, R.L.; Kimata, K. Mice deficient in heparan sulfate 6-O-sulfotransferase-1 exhibit defective heparan sulfate biosynthesis, abnormal placentation, and late embryonic lethality. J. Biol. Chem. 2007, 282, 15578-15588. [CrossRef] [PubMed]

112. Clegg, J.M.; Conway, C.D.; Howe, K.M.; Price, D.J.; Mason, J.O.; Turnbull, J.E.; Albert Basson, M.; Pratt, T. Heparan sulfotransferases Hs6st1 and Hs2st keep Erk in check for mouse corpus callosum development. J. Neurosci. 2014, 34, $2389-2401$. [CrossRef]

113. Howard, S.R.; Oleari, R.; Poliandri, A.; Chantzara, V.; Fantin, A.; Ruiz-Babot, G.; Metherell, L.A.; Cabrera, C.P.; Barnes, M.R.; Wehkalampi, K.; et al. HS6ST1 Insufficiency Causes Self-Limited Delayed Puberty in Contrast with Other GnRH Deficiency Genes. J. Clin. Endocrinol. Metab. 2018, 103, 3420-3429. [CrossRef] [PubMed]

114. Anower-E-Khuda, M.F.; Habuchi, H.; Nagai, N.; Habuchi, O.; Yokochi, T.; Kimata, K. Heparan sulfate 6-O-sulfotransferase isoform-dependent regulatory effects of heparin on the activities of various proteases in mast cells and the biosynthesis of 6-O-sulfated heparin. J. Biol. Chem. 2013, 288, 3705-3717. [CrossRef] [PubMed]

115. Smits, N.C.; Kobayashi, T.; Srivastava, P.K.; Skopelja, S.; Ivy, J.A.; Elwood, D.J.; Stan, R.V.; Tsongalis, G.J.; Sellke, F.W.; Gross, P.L.; et al. HS3ST1 genotype regulates antithrombin's inflammomodulatory tone and associates with atherosclerosis. Matrix Biol. 2017, 63, 69-90. [CrossRef]

116. HajMohammadi, S.; Enjyoji, K.; Princivalle, M.; Christi, P.; Lech, M.; Beeler, D.; Rayburn, H.; Schwartz, J.J.; Barzegar, S.; de Agostini, A.I.; et al. Normal levels of anticoagulant heparan sulfate are not essential for normal hemostasis. J. Clin. Investig. 2003, 111, 989-999. [CrossRef]

117. Otsuki, S.; Alvarez-Garcia, O.; Lotz, M.K.; Neo, M. Role of heparan sulfate 6-0 endosulfatases in intervertebral disc homeostasis Histol. Histopathol. 2019, 34, 1051-1060. [CrossRef]

118. Touahri, Y.; Escalas, N.; Benazeraf, B.; Cochard, P.; Danesin, C.; Soula, C. Sulfatase 1 promotes the motor neuron-tooligodendrocyte fate switch by activating Shh signaling in Olig2 progenitors of the embryonic ventral spinal cord. J. Neurosci. 2012, 32, 18018-18034. [CrossRef] [PubMed]

119. Kalus, I.; Rohn, S.; Puvirajesinghe, T.M.; Guimond, S.E.; Eyckerman-Kölln, P.J.; Ten Dam, G.; Van Kuppevelt, T.H.; Turnbull, J.E.; Dierks, T. Sulf1 and Sulf2 differentially modulate heparan sulfate proteoglycan sulfation during postnatal cerebellum development: Evidence for neuroprotective and neurite outgrowth promoting functions. PLoS ONE 2015, 10, e0139853. [CrossRef]

120. Jiang, W.; Ishino, Y.; Hashimoto, H.; Keino-Masu, K.; Masu, M.; Uchimura, K.; Kadomatsu, K.; Yoshimura, T.; Ikenaka, K. Sulfatase 2 Modulates Fate Change from Motor Neurons to Oligodendrocyte Precursor Cells through Coordinated Regulation of Shh Signaling with Sulfatase 1. Dev. Neurosci. 2017, 39, 361-374. [CrossRef]

121. Holst, C.R.; Bou-Reslan, H.; Gore, B.B.; Wong, K.; Grant, D.; Chalasani, S.; Carano, R.A.; Frantz, G.D.; Tessier-Lavigne, M.; Bolon, B.; et al. Secreted sulfatases Sulf1 and Sulf2 have overlapping yet essential roles in mouse neonatal survival. PLoS ONE 2007, 2, e575. [CrossRef]

122. Maltseva, I.; Chan, M.; Kalus, I.; Dierks, T.; Rosen, S.D. The SULFs, Extracellular Sulfatases for Heparan Sulfate, Promote the Migration of Corneal Epithelial Cells during Wound Repair. PLoS ONE 2013, 8, e0069642. [CrossRef] 
123. Korf-Klingebiel, M.; Reboll, M.R.; Grote, K.; Schleiner, H.; Wang, Y.; Wu, X.; Klede, S.; Mikhed, Y.; Bauersachs, J.; Klintschar, M.; et al. Heparan sulfate-editing extracellular sulfatases enhance VEGF bioavailability for ischemic heart repair. Circ. Res. 2019, 125, 787-801. [CrossRef] [PubMed]

124. Ratzka, A.; Kalus, I.; Moser, M.; Dierks, T.; Mundlos, S.; Vortkamp, A. Redundant function of the heparan sulfate 6-Oendosulfatases Sulf1 and Sulf2 during skeletal development. Dev. Dyn. 2008, 237, 339-353. [CrossRef] [PubMed]

125. Kalus, I.; Salmen, B.; Viebahn, C.; von Figura, K.; Schmitz, D.; D’Hooge, R.; Dierks, T. Differential involvement of the extracellular 6-O-endosulfatases Sulf1 and Sulf2 in brain development and neuronal and behavioural plasticity. J. Cell. Mol. Med. 2009, 13, 4505-4521. [CrossRef]

126. Ohayon, D.; Escalas, N.; Cochard, P.; Glise, B.; Danesin, C.; Soula, C. Sulfatase 2 promotes generation of a spinal cord astrocyte subtype that stands out through the expression of Olig2. Glia 2019, 67, 1478-1495. [CrossRef] [PubMed]

127. Nakamura, I.; Fernandez-Barrena, M.G.; Ortiz-Ruiz, M.C.; Almada, L.L.; Hu, C.; Elsawa, S.F.; Mills, L.D.; Romecin, P.A.; Gulaid, K.H.; Moser, C.D.; et al. Activation of the transcription factor gli1 by wnt signaling underlies the role of SULFATASE 2 as a regulator of tissue regeneration. J. Biol. Chem. 2013, 288, 21389-21398. [CrossRef] [PubMed]

128. Okada, T.; Keino-Masu, K.; Nagamine, S.; Kametani, F.; Ohto, T.; Hasegawa, M.; Van Kuppevelt, T.H.; Kunita, S.; Takahashi, S.; Masu, M. Desulfation of Heparan Sulfate by Sulf1 and Sulf2 Is Required for Corticospinal Tract Formation. Sci. Rep. 2017, 7, 13847. [CrossRef]

129. Aizawa, S.; Okada, T.; Keino-Masu, K.; Doan, T.H.; Koganezawa, T.; Akiyama, M.; Tamaoka, A.; Masu, M. Abnormal Pyramidal Decussation and Bilateral Projection of the Corticospinal Tract Axons in Mice Lacking the Heparan Sulfate Endosulfatases, Sulf1 and Sulf2. Front. Mol. Neurosci. 2020, 12, 333. [CrossRef]

130. Takashima, Y.; Keino-Masu, K.; Yashiro, H.; Hara, S.; Suzuki, T.; van Kuppevelt, T.H.; Masu, M.; Nagata, M. Heparan sulfate 6-o-endosulfatases, sulf1 and sulf2, regulate glomerular integrity by modulating growth factor signaling. Am. J. Physiol. Ren. Physiol. 2016, 310, F395-F408. [CrossRef]

131. Ai, X.; Kitazawa, T.; Do, A.T.; Kusche-Gullberg, M.; Labosky, P.A.; Emerson, C.P. SULF1 and SULF2 regulate heparan sulfatemediated GDNF signaling for esophageal innervation. Development 2007, 134, 3327-3338. [CrossRef]

132. Langsdorf, A.; Schumacher, V.; Shi, X.; Tran, T.; Zaia, J.; Jain, S.; Taglienti, M.; Kreidberg, J.A.; Fine, A.; Ai, X. Expression regulation and function of heparan sulfate 6-O-endosulfatases in the spermatogonial stem cell niche. Glycobiology 2011, 21, 152-161. [CrossRef]

133. Yue, X. Epithelial deletion of sulf2 exacerbates bleomycin-induced lung injury, inflammation, and mortality. Am. J. Respir. Cell Mol. Biol. 2017, 57, 560-569. [CrossRef] [PubMed]

134. Deligny, A.; Dierker, T.; Dagälv, A.; Lundequist, A.; Eriksson, I.; Nairn, A.V.; Moremen, K.W.; Merry, C.L.R.; Kjellén, L. NDST2 (N-deacetylase/N-sulfotransferase-2) enzyme regulates heparan sulfate chain length. J. Biol. Chem. 2016, 291, 18600-18607. [CrossRef] [PubMed]

135. Merry, C.L.R.; Bullock, S.L.; Swan, D.C.; Backen, A.C.; Lyon, M.; Beddington, R.S.P.; Wilson, V.A.; Gallagher, J.T. The Molecular Phenotype of Heparan Sulfate in the Hs2st- / - Mutant Mouse. J. Biol. Chem. 2001, 276, 35429-35434. [CrossRef] [PubMed]

136. Alhasan, A.A.; Spielhofer, J.; Kusche-Gullberg, M.; Kirby, J.A.; Ali, S. Role of 6-O-sulfated heparan sulfate in chronic renal fibrosis. J. Biol. Chem. 2014, 289, 20295-20306. [CrossRef] [PubMed]

137. Kamimura, K.; Rhodes, J.M.; Ueda, R.; McNeely, M.; Shukla, D.; Kimata, K.; Spear, P.G.; Shworak, N.W.; Nakato, H. Regulation of Notch signaling by Drosophila heparan sulfate 3-O sulfotransferase. J. Cell Biol. 2004, 166, 1069-1079. [CrossRef] [PubMed]

138. Vaidyanathan, D.; Paskaleva, E.; Vargason, T.; Ke, X.; Mccallum, S.A.; Linhardt, R.J.; Dordick, J.S. Elucidating the unusual reaction kinetics of D-glucuronyl C5-epimerase. Glycobiology 2020, 30, 847-858. [CrossRef] [PubMed]

139. Vaidyanathan, D.; Williams, A.; Dordick, J.S.; Koffas, M.A.G.; Linhardt, R.J. Engineered heparins as new anticoagulant drugs. Bioeng. Transl. Med. 2017, 2, 17-30. [CrossRef] [PubMed]

140. Sun, Y.; Zhang, W.; Xu, Y.-H.; Quinn, B.; Dasgupta, N.; Liou, B.; Setchell, K.D.R.; Grabowski, G.A. Substrate compositional variation with tissue/region and Gba1 mutations in mouse models-implications for Gaucher disease. PLoS ONE 2013, 8, e57560. [CrossRef]

141. Xian, C.; Zhu, M.; Nong, T.; Li, Y.; Xie, X.; Li, X.; Li, J.; Li, J.; Wu, J.; Shi, W.; et al. A novel mutation in EXT2 caused hereditary multiple exostoses through reducing the synthesis of heparan sulfate. Genet. Mol. Biol. 2021, 44. [CrossRef]

142. Platt, F.M.; d'Azzo, A.; Davidson, B.L.; Neufeld, E.F.; Tifft, C.J. Lysosomal storage diseases. Nat. Rev. Dis. Prim. 2018, 4, 27. [CrossRef]

143. Boustany, R.-M.N. Lysosomal storage diseases-the horizon expands. Nat. Rev. Neurol. 2013, 9, 583-598. [CrossRef] [PubMed]

144. Neufeld, E.; Muenzer, J. The mucopolysaccharidoses. In The Metabolic and Molecular bases of Inherited Disease; McGraw Hill: New York, NY, USA, 2001; pp. 3421-3452.

145. Marques, A.R.A.; Saftig, P. Lysosomal storage disorders-Challenges, concepts and avenues for therapy: Beyond rare diseases. J. Cell Sci. 2019, 132, 221739. [CrossRef] [PubMed]

146. Kosuga, M.; Mashima, R.; Hirakiyama, A.; Fuji, N.; Kumagai, T.; Seo, J.-H.; Nikaido, M.; Saito, S.; Ohno, K.; Sakuraba, H.; et al. Molecular diagnosis of 65 families with mucopolysaccharidosis type II (Hunter syndrome) characterized by 16 novel mutations in the IDS gene: Genetic, pathological, and structural studies on iduronate-2-sulfatase. Mol. Genet. Metab. 2016, 118, 190-197. [CrossRef] 
147. Vafiadaki, E.; Cooper, A.; Heptinstall, L.E.; Hatton, C.E.; Thornley, M.; Wraith, J.E. Mutation analysis in 57 unrelated patients with MPS II (Hunter's disease). Arch. Dis. Child. 1998, 79, 237-241. [CrossRef] [PubMed]

148. Lai, C.H.; Chun, H.H.; Nahas, S.A.; Mitui, M.; Gamo, K.M.; Du, L.; Gatti, R.A. Correction of ATM gene function by aminoglycosideinduced read-through of premature termination codons. Proc. Natl. Acad. Sci. USA 2004, 101, 15676-15681. [CrossRef] [PubMed]

149. Chien, Y.-H.; Lee, N.-C.; Thurberg, B.L.; Chiang, S.-C.; Zhang, X.K.; Keutzer, J.; Huang, A.-C.; Wu, M.-H.; Huang, P.-H.; Tsai, F.-J.; et al. Pompe Disease in Infants: Improving the Prognosis by Newborn Screening and Early Treatment. Pediatrics 2009, 124, e1116-e1125. [CrossRef] [PubMed]

150. Schielen, P.; Kemper, E.; Gelb, M. Newborn Screening for Lysosomal Storage Diseases: A Concise Review of the Literature on Screening Methods, Therapeutic Possibilities and Regional Programs. Int. J. Neonatal Screen. 2017, 3, 6. [CrossRef] [PubMed]

151. Elliott, S.; Buroker, N.; Cournoyer, J.J.; Potier, A.M.; Trometer, J.D.; Elbin, C.; Schermer, M.J.; Kantola, J.; Boyce, A.; Turecek, F.; et al. Pilot study of newborn screening for six lysosomal storage diseases using Tandem Mass Spectrometry. Mol. Genet. Metab. 2016, 118, 304-309. [CrossRef]

152. Liao, H.-C.; Chiang, C.-C.; Niu, D.-M.; Wang, C.-H.; Kao, S.-M.; Tsai, F.-J.; Huang, Y.-H.; Liu, H.-C.; Huang, C.-K.; Gao, H.-J.; et al. Detecting multiple lysosomal storage diseases by tandem mass spectrometry-a national newborn screening program in Taiwan. Clin. Chim. Acta 2014, 431, 80-86. [CrossRef]

153. Sonoda, H.; Morimoto, H.; Yoden, E.; Koshimura, Y.; Kinoshita, M.; Golovina, G.; Takagi, H.; Yamamoto, R.; Minami, K.; Mizoguchi, A.; et al. A Blood-Brain-Barrier-Penetrating Anti-human Transferrin Receptor Antibody Fusion Protein for Neuronopathic Mucopolysaccharidosis II. Mol. Ther. 2018, 26, 1366-1374. [CrossRef]

154. Sardiello, M.; Palmieri, M.; di Ronza, A.; Medina, D.L.; Valenza, M.; Gennarino, V.A.; Di Malta, C.; Donaudy, F.; Embrione, V.; Polishchuk, R.S.; et al. A Gene Network Regulating Lysosomal Biogenesis and Function. Science 2009, 325, 473-477. [CrossRef]

155. Martina, J.A.; Diab, H.I.; Brady, O.A.; Puertollano, R. TFEB and TFE3 are novel components of the integrated stress response. EMBO J. 2016, 35, 479-495. [CrossRef]

156. Muenzer, J. Overview of the mucopolysaccharidoses. Rheumatology 2011, 50, v4-v12. [CrossRef]

157. Demydchuk, M.; Hill, C.H.; Zhou, A.; Bunkóczi, G.; Stein, P.E.; Marchesan, D.; Deane, J.E.; Read, R.J. Insights into Hunter syndrome from the structure of iduronate-2-sulfatase. Nat. Commun. 2017, 8, 15786. [CrossRef] [PubMed]

158. Dierks, T.; Dickmanns, A.; Preusser-Kunze, A.; Schmidt, B.; Mariappan, M.; Von Figura, K.; Ficner, R.; Rudolph, M.G. Molecular basis for multiple sulfatase deficiency and mechanism for formylglycine generation of the human formylglycine-generating enzyme. Cell 2005, 121, 541-552. [CrossRef] [PubMed]

159. Garcia, A.R.; Pan, J.; Lamsa, J.C.; Muenzer, J. The characterization of a murine model of mucopolysaccharidosis II (Hunter syndrome). J. Inherit. Metab. Dis. 2007, 30, 924-934. [CrossRef] [PubMed]

160. Muenzer, J. Early initiation of enzyme replacement therapy for the mucopolysaccharidoses. Mol. Genet. Metab. 2014, 111, 63-72. [CrossRef] [PubMed]

161. Muenzer, J.; Hendriksz, C.J.; Fan, Z.; Vijayaraghavan, S.; Perry, V.; Santra, S.; Solanki, G.A.; Mascelli, M.A.; Pan, L.; Wang, N.; et al. A phase I/II study of intrathecal idursulfase-IT in children with severe mucopolysaccharidosis II. Genet. Med. 2016, $18,73-81$. [CrossRef]

162. Tomatsu, S.; Gutierrez, M.A.; Ishimaru, T.; Peña, O.M.; Montaño, A.M.; Maeda, H.; Velez-Castrillon, S.; Nishioka, T.; Fachel, A.A.; Cooper, A.; et al. Heparan sulfate levels in mucopolysaccharidoses and mucolipidoses. J. Inherit. Metab. Dis. 2005, $28,743-757$. [CrossRef]

163. Hudry, E.; Vandenberghe, L.H. Therapeutic AAV Gene Transfer to the Nervous System: A Clinical Reality. Neuron 2019, 101, 839-862. [CrossRef]

164. Mantovani, A.; Sozzani, S.; Locati, M.; Allavena, P.; Sica, A. Macrophage polarization: Tumor-associated macrophages as a paradigm for polarized M2 mononuclear phagocytes. Trends Immunol. 2002, 23, 549-555. [CrossRef] 